\title{
European Regulatory Framework and Particulate Matter Emissions of Gasoline Light-Duty Vehicles: A Review
}

\author{
Barouch Giechaskiel $^{1, *}$, Ameya Joshi ${ }^{2}$, Leonidas Ntziachristos ${ }^{3}$ and Panagiota Dilara 4 \\ 1 European Commission, Joint Research Centre, 21027 Ispra, Italy \\ Corning Incorporated, Corning, NY 14831, USA \\ 3 Aristotle University Thessaloniki, Laboratory of Heat Transfer and Environmental Engineering, \\ 54124 Thessaloniki, Greece \\ 4 European Commission, DG-GROW, 1040 Brussels, Belgium \\ * Correspondence: Barouch.Giechaskiel@ec.europa.eu; Tel.: +39-0332-78-5312
}

Received: 15 June 2019; Accepted: 3 July 2019; Published: 4 July 2019

\begin{abstract}
The particulate matter (PM) emissions of gasoline vehicles were much lower than those of diesel vehicles until the introduction of diesel particulate filters (DPFs) in the early 2000s. At the same time, gasoline direct injection (GDI) engines started to become popular in the market due to their improved efficiency over port fuel injection (PFI) ones. However, the PM mass and number emissions of GDI vehicles were higher than their PFI counterparts and diesel ones equipped with DPFs. Stringent PM mass levels and the introduction of particle number limits for GDI vehicles in the European Union (EU) resulted in significant PM reductions. The EU requirement to fulfill the proposed limits on the road resulted to the introduction of gasoline particulate filters (GPFs) in EU GDI models. This review summarizes the evolution of PM mass emissions from gasoline vehicles placed in the market from early 1990s until 2019 in different parts of the world. The analysis then extends to total and nonvolatile particle number emissions. Care is given to reveal the impact of ambient temperature on emission levels. The discussion tries to provide scientific input to the following policy-relevant questions. Whether particle number limits should be extended to gasoline PFI vehicles, whether the lower limit of $23 \mathrm{~nm}$ for particle number measurements should be decreased to $10 \mathrm{~nm}$, and whether low ambient temperature tests for PM should be included.
\end{abstract}

Keywords: air pollution; vehicle emissions; port fuel injection (PFI); gasoline direct injection (GDI); particle number (PN); particulate matter (PM); low temperature; sub-23 nm; chemical composition

\section{Introduction}

Driven by the greenhouse gas emission reduction policies and the goal to keep the global temperature increase below $2{ }^{\circ} \mathrm{C}$, the European Union (EU) is committed to reducing $\mathrm{CO}_{2}$ emissions by $20 \%$ in 2020, and by $80-95 \%$ in 2050 compared to 1990 levels [1]. The Transport White Paper [2] describes how the transport system can reduce its emissions by $60 \%$ in the same period: the target is a $50 \%$ shift away from conventionally fueled cars by 2030, phasing them out from cities by 2050 . Thus, a big shift to cleaner cars and more sustainable fuels is required. Similar policies are followed globally [3,4]. One contributor in this direction is the replacement of traditional port fuel injection (PFI) gasoline engines by boosted, more efficient, downsized gasoline direct injection (GDI) engines [5].

GDI engines are not new: 100 years ago the very first test rig run of a GDI engine was successfully carried out [6]. Subsequently, this engine was produced for use in boats in the 1930s and for aircrafts in the 1940s. The first serial application in passenger vehicles started in the 1950s [7]. Research into GDIs increased in the 1990s with the development of engine management systems capable of supporting the 
additional fuel-metering complexity [8]. The first modern GDI vehicle was introduced in 1996 [9]. The real boost was given later by the European Commission (EC) Recommendation 1999/125/EC to reduce $\mathrm{CO}_{2}$ emissions from passenger cars. The EU first introduced mandatory $2015 \mathrm{CO}_{2}$ standards for new passenger cars in 2009 with Regulation (EC) No 443/2009.

GDI passenger cars for the first time exceeded sales of diesel cars in EU in 2017 (51\% vs. 44\%) [10]. In the USA GDI cars first penetrated the market in 2007 and light trucks in 2008 [11]. In 2017, the GDI market share (cars and trucks combined) was 50\% in the United States (US) with expectations to grow [12].

There have been many review studies on GDI emissions and their control (Table 1). The current study summarizes the regulatory framework: it starts with regulations and shows how and where we have arrived today. It then discusses future perspectives. In contrast to earlier reviews, our study isolates emissions from commercially available vehicles and does not address emissions from engines since only the former can be assumed representative of real-world emissions.

Table 1. Review studies on gasoline engines and their emissions reductions. $Y=$ Yes (addressed).

\begin{tabular}{|c|c|c|c|c|c|}
\hline Review & Health & Engine & Fuel & Aftertreatment & PM/SPN \\
\hline Book 2009 [13] & - & $\mathrm{Y}$ & $\mathrm{Y}$ & $(\mathrm{Y})$ & - \\
\hline Book 2010 [14] & - & $\mathrm{Y}$ & $\mathrm{Y}$ & $(\mathrm{Y})$ & - \\
\hline Book 2019 [15] & $\mathrm{Y}$ & $\mathrm{Y}$ & Y & Y & Y \\
\hline Book 2019 [16] & $\mathrm{Y}$ & $\mathrm{Y}$ & Y & $\mathrm{Y}$ & Y \\
\hline Paper 1999 [17] & - & $\mathrm{Y}$ & - & - & - \\
\hline Paper 2007 [5] & - & $\mathrm{Y}$ & - & - & - \\
\hline Paper 2014 [18] & $\mathrm{Y}$ & - & - & - & $\mathrm{Y}$ \\
\hline Paper 2014 [19] & - & $\mathrm{Y}$ & - & $\mathrm{Y}$ & $\mathrm{Y}$ \\
\hline Paper 2015 [20] & - & - & - & $\mathrm{Y}$ & Y \\
\hline Paper 2015 [21] & Y & $\mathrm{Y}$ & $\mathrm{Y}$ & $\mathrm{Y}$ & Y \\
\hline Paper 2017 [22] & - & $\mathrm{Y}$ & $\mathrm{Y}$ & $\mathrm{Y}$ & $\mathrm{Y}$ \\
\hline Paper 2018 [23] & - & $\mathrm{Y}$ & $\mathrm{Y}$ & $\mathrm{Y}$ & Y \\
\hline Paper 2018 [24] & - & $\mathrm{Y}$ & Y & - & Y \\
\hline Paper 2018 [25] & - & $\mathrm{Y}$ & $\mathrm{Y}$ & $\mathrm{Y}$ & $\mathrm{Y}$ \\
\hline Paper 2019 [26] & - & $\mathrm{Y}$ & - & $\mathrm{Y}$ & Y \\
\hline Paper 2019 [27] & - & $\mathrm{Y}$ & $\mathrm{Y}$ & - & $\mathrm{Y}$ \\
\hline Annual reviews [28-35] & - & Y & Y & $\mathrm{Y}$ & Y \\
\hline
\end{tabular}

PM = Particulate Matter; SPN = Solid Particle Number.

\section{Definitions and Fundamentals of Gasoline Engines and Filters}

\subsection{Gasoline Engine Fundamentals}

In the EU legislation, a positive ignition (PI) engine is the term used for the spark ignition (SI) engine, in which combustion is initiated by a localized energy supply unit from a source external to combustion. The majority of PI engines use gasoline (petrol) as fuel; other fuels, such as CNG (compressed natural gas) or liquefied petroleum gas (LPG), can also be employed in PI engines, but these are not discussed in this paper.

In conventional gasoline engines, fuel and air are mixed in the intake system and are introduced together into the cylinder. The older technology for the mixture preparation was the carburetor, later it was replaced by inlet port fuel injection (PFI) systems: initially using a single injector in the inlet manifold, and later using multipoint port injection (MPI) systems. Vehicles utilizing such mixture preparation concepts will be referred to as PFIs in this paper. When the fuel is directly injected into the cylinder the engine may be called gasoline direct injection (GDI), direct petrol injection, spark-ignited direct injection (SIDI) or fuel-stratified injection (FSI) one. In this paper, the GDI acronym will be used to refer to vehicles with such engines. Engines using some combination of PFI and GDI appeared in the Japanese and US markets in 2005 [36] and have spread since then [26,37]. 
GDIs can achieve fuel economy savings compared to PFIs. The efficiency gains mostly resides from the fact that the engine breathes and compresses air and not air and fuel mixture, the resistance to knock that allows higher compression ratio and the in-cylinder cooling of the charge. The GDI combustion systems can be distinguished depending on the concept employed to achieve charge stratification [5] to wall-guided, first-generation air-guided (or side mounted), or second-generation spray-guided (or top mounted). The three combustion modes used until recently are [8] as follows; at low load, fuel is injected during the compression stroke, the charge is stratified with an overall lean mixture. At medium load, fuel is injected during the intake stroke and the charge is homogeneous with lean mixtures. At high load, injection takes place during the intake stroke; the charge is homogeneous with stoichiometric mixtures. However, lean stratified operation has high particulate emissions [38], and needs lean-burn $\mathrm{NO}_{\mathrm{x}}$ aftertreatment to fulfill the legislative limits $[29,39]$. The regeneration of the $\mathrm{NO}_{\mathrm{x}}$ aftertreatment devices is achieved with rich operation that can increase PM emissions and fuel consumption so removing any efficiency benefits [40]. Consequently, modern GDIs work stoichiometrically.

Gasoline engines have been using three-way catalytic converters (TWC) since the 1970s [41]. While the availability of oxygen in the exhaust gas is essential for the oxidation of $\mathrm{CO}$ and $\mathrm{HC}$ (to water and $\mathrm{CO}_{2}$ ), the reduction of $\mathrm{NO}_{x}$ is inhibited by the presence of oxygen. Thus, the catalyst can simultaneously reduce all three pollutants only at stoichiometric conditions. Modern TWCs are extremely efficient with nearly complete conversion under hot engine running conditions, so most of the emissions occur during the first few tens of seconds after engine start, before catalyst light-off. Improvements in tailpipe gas emissions control from gasoline engines mostly target a faster catalyst light-off.

In the conventional PFI engine, fuel is injected into the intake port so that fuel and air flow simultaneously into the combustion chamber during the intake process, and a homogeneous air-fuel mixture is formed. On the other hand, in GDI engines, fuel is sprayed directly into the combustion chamber, which leads to incomplete fuel evaporation due to the limited time available for fuel and air mixing, resulting in localized rich combustion and particulate matter (PM) formation [42,43]. Additionally, a small amount of fuel may impinge on the piston and make direct contact with the cold cylinder walls, which may lead to diffusion combustion and subsequent PM formation [44]. Wall-wetting can induce the formation of a solid nucleation mode consisting of ash derived from metallic lubrication oil additives [45]. The PM levels are much lower for stoichiometric GDIs. Finally, injector deposits may store fuel which is subsequently burned with sooting combustion $[25,46]$. Fouling of injectors has been shown to significantly increase PM emissions [47,48]. Finally, fuel composition can also influence the emission levels [49], notably the PM emissions are strongly correlated with the aromatics levels in the fuel [50]. A detailed discussion of these items has already been conducted before (Table 1) and is therefore not repeated here.

Reduction in PM emissions from GDI engines can be achieved through hardware or software improvements (including fuel injection timing, shaping and pressure) [26,51]. Another solution to reduce PM emissions from GDI engines is the use of gasoline particulate filters (GPFs) [23].

\subsection{GPF Performance}

It is not the intention of this paper to give an exhaustive description of the performance of GPFs, as more dedicated studies have done in the past $[16,23]$. Here we only provide a brief overview of some aspects of GPF performance that can be observed as one compares GDI particulate emissions over time.

The GPFs can be installed close-coupled to the engine or under the floor, with or without a TWC coating [52-54]. For a GPF, studies find lower filtration efficiency at the close-coupled position: due to the higher temperatures the flow velocity is higher [55] and a smaller soot cake is formed [56]. Catalyst coated or catalyzed or catalytic GPFs (four-way catalysts) can be used within exhaust aftertreatment systems to control gaseous emissions providing equivalent performance by replacing some or all of the catalyst volume, consequently reducing the overall volume of the aftertreatment system and enabling more compact designs [57]. Due to the continued worldwide tightening of automotive 
emission standards, catalyzed GPFs can supplement the performance of the existing three-way catalytic devices [58]. GPF coating can enhance soot oxidation [59]. There is a trade-off between improved gaseous emissions conversion activity and filtration efficiency, and increased system backpressure and component cost $[53,60]$.

\subsubsection{Durability and Ash Accumulation}

In EU, with Euro 5 and Euro 6, the useful vehicle life (durability) is specified at 160,000 $\mathrm{km}$. California LEV III, starting in 2025, increased the durability requirements from 120,000 miles to 150,000 miles $(240,000 \mathrm{~km})$. In China, the durability is increased to $240,000 \mathrm{~km}$ starting with China $6 \mathrm{~b}$ (2023). The durability of GPFs is affected by thermal aging, as with three-way catalytic converters, and in addition by severe thermal stress due to localized soot oxidation. Thus, the typical thermal aging of TWC is not appropriate for GPFs [61]. The proposed protocol should include thermal aging, ash loading and soot accumulation and regeneration [62]. One study that followed such protocol showed robust performance of a catalyzed GPF in the underfloor position, with filtration efficiency improving from $74 \%$ for a fresh filter to $>99 \%$ after aging equivalent to full useful life of $200,000 \mathrm{~km}$ (China 6b). Installed coated GPFs on vehicles have also demonstrated a good level of catalytic activity and filtration efficiency after full useful life aging and over a range of driving conditions $[60,63,64]$.

Over their lifetime, GPFs collect inorganic ash particles derived from lubricating oil, engine wear, and corrosion of upstream exhaust pipes [65]. GPFs have to be designed to accumulate ash without a significant increase in pressure drop. Several studies have measured the ash accumulation rates, with a range of 0.1 to $0.3 \mathrm{mg} / \mathrm{km}$, which translates to $24-72 \mathrm{~g}$ over the useful vehicle life of $240,000 \mathrm{~km}$ [66]. The accumulation of ash is associated with an increase in clean (i.e., without soot) pressure drop. However, the presence of an ash layer is also associated with an increase in filtration efficiency as the ash accumulation along the wall pores reduces soot particles from penetrating the filter wall $[60,63,67]$. As a consequence, and remarkably, the filtration performance of a GPF only improves with vehicle age [68]. Furthermore, the presence of ash also reduces the soot loaded pressure drop associated with deep-bed filtration. Only a small amount of ash is required to increase the filtration efficiency significantly. In one study [69] the overall filtration efficiency on a test cycle was found to increase from 75 to $90 \%$, when the filter was loaded with $1.5 \mathrm{~g} / \mathrm{L}$ of artificial ash. Mileage accumulation on vehicles equipped with GPFs shows that $3000 \mathrm{~km}$ can increase the filtration efficiency by 10 to $15 \%$ [68]. This justifies the deterioration factor of 1 (e.g., no deterioration) for particulate emissions in the regulations, which, however, assumes proper management of the filter to prevent damages over its useful life.

\subsubsection{Regeneration}

GDI engines have lower engine-out PM emissions than diesel engines, and much less soot is accumulated. Soot regeneration can occur at exhaust gas temperatures $\sim 500^{\circ} \mathrm{C}$ even with little available oxygen content in the exhaust [70]. The low temperature $\left(200-400{ }^{\circ} \mathrm{C}\right)$ reaction with $\mathrm{NO}_{2}$ and soot is limited because most of $\mathrm{NO}$ and $\mathrm{NO}_{2}$ are reduced from three-way catalyst upstream of the GPF. GDI soot morphology and reactivity have also been studied and are sensitive to engine operating conditions, injection parameters, and the presence of ash [71]. Due to high temperatures associated with gasoline exhaust, the filter is expected to be passively regenerating for much of the vehicle operation. Fuel cut events associated with vehicle deceleration lead to abundant oxygen ( $20 \%$ concentration) in the exhaust, which along with the high temperatures and low flow rates are sufficient to oxidize the accumulated soot [70]. Nevertheless, active regeneration strategies are also being proposed for certain conditions such as slow driving for extended durations, with low exhaust temperatures, such as those typically encountered in urban congested driving. To initiate soot oxidation, the GPF inlet temperature is elevated through engine methods (e.g., spark retard) or generating an exotherm on the three-way catalyst via air-to-fuel ratio modulation [72]. Whether initiated through passive or active means, soot oxidation is exothermic and leads to temperature rise within the GPF. The maximum temperature within the GPF depends on the soot load and inlet gas temperature and increases by $\sim 60-100{ }^{\circ} \mathrm{C}$ per 
$\mathrm{g} / \mathrm{L}$ of soot load [73]. Maximum temperatures exceeding $1100^{\circ} \mathrm{C}$ have been noted at very high soot loads $(>5 \mathrm{~g} / \mathrm{L})$, and GPFs can withstand these high temperatures. However, the filtration efficiency might decrease due to cracks if these temperatures are exceeded.

When filter regeneration is triggered the filtration efficiency of particles $>23 \mathrm{~nm}$ drops from approximately $90 \%$ to $60 \%$ due to the reduced soot cake [74]. The filtration efficiency for smaller particles is higher due to their higher diffusivity [51], thus higher filtration efficiencies are expected for sub-23 nm particles. Typically tailpipe emissions with the use of GPF comfortably meet the limit of $6 \times 10^{11}$ particles per $\mathrm{km}$ even with the inclusion of particles below $23 \mathrm{~nm}$ [75]. However, due to the high exhaust gas temperature many particles $<30 \mathrm{~nm}$ can be formed downstream of the GPF $[56,61,74]$. The nature of these particles is not clear yet: they could be renucleated semivolatile particles downstream of the thermal pretreatment unit of the particle number measurement systems or even nonvolatile particles formed between the vehicle and the dilution tunnel. A recent study showed that particle number systems at the tailpipe or the dilution tunnel can have high differences in the sub-23 nm concentrations during regeneration events [76]. Thus, more research is needed on the topic. Finally, if GPFs will include and use active regeneration systems, appropriate correction factors (Ki) that take into account the contribution of the regeneration emissions will have to be evaluated for the regulations [75].

\section{Regulations}

\subsection{Emission Standards}

In 1970, the first Emissions Directive was published under the well-known designation 70/220/EEC and focused on $\mathrm{HC}$ and CO emissions only [77]. Aftertreatment emission control technologies (catalysts) could not be used at the time due to the lead content in the gasoline fuel [41]. In 1984 the EC proposed that unleaded gasoline must be made available at the gas stations by 1989. This opened the door for the next step: Emission Directive 91/441/EEC (Euro 1) for passenger cars (only), which triggered the Europe-wide breakthrough of the (closed-loop) catalyst technology. Directive 93/59/EEC expanded this requirement to both passenger cars and light trucks. A fundamental prerequisite for the efficient operation of exhaust aftertreatment devices was having fuel with a very low sulfur content [78]. The next steps of Euro standards were preceded by the introduction of more stringent fuel regulations that required maximum gasoline sulfur content of 150 ppm in 2000 and 50 ppm in 2005. "Sulfur-free" diesel and gasoline fuels ( $\leq 10 \mathrm{ppm} \mathrm{S}$ ) had to be available from 2005, and became mandatory in 2009. Euro 2 standards were introduced with Directive 94/12/EEC (passenger cars) and 96/69/EC (light commercial vehicles). Euro 3 and Euro 4 standards were introduced with Directive 98/69/EC. The Euro 5 and Euro 6 limits were introduced with Regulation 715/2007 (amended by 692/2008), and provided the automotive industry with a longer timeline to develop strategies for meeting these demanding emission limits.

Particulate matter (PM) mass emissions were first regulated as of 1992 for diesel vehicles [79]. Positive ignition vehicles were exempted from PM standards until the Euro 4 stage. Euro $5 \mathrm{~b}$ legislation (2011) included, for the first time, a solid particle number (SPN) emission limit of $6.0 \times 10^{11} \mathrm{p} / \mathrm{km}$ (" $\mathrm{p}$ " for particles from now on) for diesel (compression ignition) vehicles based on the findings of the PMP (Particles Measurement Programme) [80,81]. A SPN emission limit of $6 \times 10^{11} \mathrm{p} / \mathrm{km}$ was introduced for GDIs with Euro 6 from September 2014 for new vehicle types and September 2015 for all vehicle models (Regulation 459/2012). However, for up to three years after these dates a particle number emission limit of $6 \times 10^{12} \mathrm{p} / \mathrm{km}$ could be applied to Euro 6 GDI vehicles upon request of the manufacturer. This three-year phase-in was allowed in the EU to extend the period of research and development needed to meet the standard.

Table 2 summarizes the Euro standards for PI vehicles. 
Table 2. European Union (EU) emission standards for positive ignition (PI) light-duty vehicles (g/km for $\mathrm{CO}, \mathrm{mg} / \mathrm{km}$ for $\mathrm{HC}_{,} \mathrm{NO}_{\mathrm{x}}, \mathrm{PM}$, and $\mathrm{p} / \mathrm{km}$ for $\mathrm{SPN}$ ).

\begin{tabular}{|c|c|c|c|c|c|c|c|c|c|c|c|}
\hline Euro & Class & Cycle & NM & AM & $\mathrm{CO}$ & HC & $\mathrm{NO}_{\mathrm{x}}$ & $\mathrm{CF}_{\mathrm{NOx}}$ & $\mathrm{PM}^{1}$ & SPN $^{1}$ & $\mathrm{CF}_{\text {SPN }}$ \\
\hline \multirow[t]{4}{*}{1} & M1, M2 & EDC & $07 /{ }^{\prime} 92$ & $01 /{ }^{\prime} 93$ & 2.72 & 970 & - & - & - & - & - \\
\hline & N1-I & & $10 /{ }^{\prime} 93$ & $10 /{ }^{\prime} 94$ & 2.72 & 970 & - & - & - & - & - \\
\hline & N1-II & & $10 /{ }^{\circ} 93$ & $10 /{ }^{\prime} 94$ & 5.17 & 1400 & - & - & - & - & - \\
\hline & N1-III & & $10 /{ }^{\prime} 93$ & $10 /{ }^{\prime} 94$ & 6.90 & 1700 & - & - & - & - & - \\
\hline \multirow[t]{4}{*}{2} & M1, M2 & & $01 /{ }^{\prime} 96$ & $01 /{ }^{\prime} 97$ & 2.20 & 500 & - & - & - & - & - \\
\hline & N1-I & & $01 /{ }^{\prime} 97$ & $10 / ' 97$ & 2.20 & 500 & - & - & - & - & - \\
\hline & N1-II & & $01 /{ }^{\prime} 98$ & $10 /{ }^{\prime} 98$ & 4.00 & 600 & - & - & - & - & - \\
\hline & N1-III & & $01 /{ }^{\prime} 98$ & $10 /{ }^{\prime} 99$ & 5.00 & 700 & - & - & - & - & - \\
\hline \multirow[t]{4}{*}{3} & M1, M2 & NEDC & $01 /{ }^{\prime} 00$ & $01 /{ }^{\prime} 01$ & 2.30 & 200 & 150 & - & - & - & - \\
\hline & N1-I & & $01 /{ }^{\prime} 00$ & $01 /{ }^{\prime} 01$ & 2.30 & 200 & 150 & - & - & - & - \\
\hline & N1-II & & $01 /{ }^{\prime} 01$ & $01 /{ }^{\prime} 02$ & 4.17 & 250 & 180 & - & - & - & - \\
\hline & N1-III & & $01 /{ }^{\prime} 01$ & $01 /{ }^{\prime} 02$ & 5.22 & 290 & 210 & - & - & - & - \\
\hline \multirow[t]{4}{*}{4} & M1, M2 & & $01 /{ }^{\prime} 05$ & $01 /{ }^{\prime} 06$ & 1.00 & 100 & 80 & - & - & - & - \\
\hline & N1-I & & $01 /{ }^{\prime} 05$ & $01 /{ }^{\prime} 06$ & 1.00 & 100 & 80 & - & - & - & - \\
\hline & N1-II & & $01 /{ }^{\prime} 06$ & $01 /{ }^{\prime} 07$ & 1.81 & 130 & 100 & - & - & - & - \\
\hline & N1-III & & $01 /{ }^{\prime} 06$ & $01 /{ }^{\prime} 07$ & 2.27 & 160 & 110 & - & - & - & - \\
\hline \multirow[t]{4}{*}{$5 a$} & M1, M2 & & 09/'09 & $09 / ׳ 11$ & 1.00 & 100 & 60 & - & 5.0 & - & - \\
\hline & N1-I & & $09 / 09$ & $09 /{ }^{\prime} 11$ & 1.00 & 100 & 60 & - & 5.0 & - & - \\
\hline & N1-II & & $09 /{ }^{\prime} 10$ & $01 /{ }^{\prime} 12$ & 1.81 & 130 & 75 & - & 5.0 & - & - \\
\hline & N1-III, N2 & & $09 /{ }^{\prime} 10$ & $01 / /^{\prime} 12$ & 2.27 & 160 & 82 & - & 5.0 & - & - \\
\hline \multirow[t]{4}{*}{$5 b$} & M1, M2 & & $09 /{ }^{\prime} 11$ & $01 /{ }^{\prime} 13$ & 1.00 & 100 & 60 & - & 4.5 & - & - \\
\hline & N1-I & & $09 /{ }^{\prime} 11$ & $01 /{ }^{\prime} 13$ & 1.00 & 100 & 60 & - & 4.5 & - & - \\
\hline & N1-II & & $09 /{ }^{\prime} 11$ & $01 /{ }^{\prime} 13$ & 1.81 & 130 & 75 & - & 4.5 & - & - \\
\hline & N1-III, N2 & & $09 /{ }^{\prime} 11$ & $01 /{ }^{\prime} 13$ & 2.27 & 160 & 82 & - & 4.5 & - & - \\
\hline \multirow[t]{4}{*}{6} & M1, M2 & & $09 /{ }^{\prime} 14$ & $09 / ׳ 15$ & 1.00 & 100 & 60 & - & 4.5 & $6 \times 10^{12}$ & - \\
\hline & N1-I & & $09 / ‘ 14$ & $09 / 15$ & 1.00 & 100 & 60 & - & 4.5 & $6 \times 10^{12}$ & - \\
\hline & N1-II & & $09 /{ }^{\prime} 15$ & $09 /{ }^{\prime} 16$ & 1.81 & 130 & 75 & - & 4.5 & $6 \times 10^{12}$ & - \\
\hline & N1-III, N2 & & $09 /{ }^{\prime} 15$ & $09 / 16$ & 2.27 & 160 & 82 & - & 4.5 & $6 \times 10^{12}$ & - \\
\hline \multirow[t]{4}{*}{$6 c$} & M1, M2 & WLTC & - & $09 /{ }^{\prime} 18$ & 1.00 & 100 & 60 & - & 4.5 & $6 \times 10^{11}$ & - \\
\hline & N1-I & & - & $09 / ‘ 18$ & 1.00 & 100 & 60 & - & 4.5 & $6 \times 10^{11}$ & - \\
\hline & N1-II & & - & $09 /{ }^{\prime} 19$ & 1.81 & 130 & 75 & - & 4.5 & $6 \times 10^{11}$ & - \\
\hline & N1-III, N2 & & - & 09/'19 & 2.27 & 160 & 82 & - & 4.5 & $6 \times 10^{11}$ & - \\
\hline \multirow{4}{*}{$\begin{array}{l}6 \mathrm{~d}- \\
\text { temp }\end{array}$} & M1, M2 & & $09 / ‘ 17$ & $09 / 19$ & 1.00 & 100 & 60 & 2.1 & 4.5 & $6 \times 10^{11}$ & $1.5^{2}$ \\
\hline & N1-I & & $09 /{ }^{\prime} 17$ & $09 /{ }^{\prime} 19$ & 1.00 & 100 & 60 & 2.1 & 4.5 & $6 \times 10^{11}$ & $1.5^{2}$ \\
\hline & N1-II & & $09 /{ }^{\prime} 18$ & $09 / 20$ & 1.81 & 130 & 75 & 2.1 & 4.5 & $6 \times 10^{11}$ & $1.5^{2}$ \\
\hline & N1-III, N2 & & $09 /{ }^{\prime} 18$ & $09 / 20$ & 2.27 & 160 & 82 & 2.1 & 4.5 & $6 \times 10^{11}$ & $1.5^{2}$ \\
\hline \multirow[t]{4}{*}{$6 \mathrm{~d}$} & M1, M2 & & $01 /{ }^{\prime} 20$ & $01 / / 21$ & 1.00 & 100 & 60 & $1.43^{2}$ & 4.5 & $6 \times 10^{11}$ & $1.5^{2}$ \\
\hline & N1-I & & $01 /{ }^{\prime} 20$ & $01 / / 21$ & 1.00 & 100 & 60 & $1.43^{2}$ & 4.5 & $6 \times 10^{11}$ & $1.5^{2}$ \\
\hline & N1-II & & $01 /{ }^{\prime} 20$ & $01 / / 22$ & 1.81 & 130 & 75 & $1.43^{2}$ & 4.5 & $6 \times 10^{11}$ & $1.5^{2}$ \\
\hline & N1-III, N2 & & $01 /{ }^{\prime} 20$ & $01 /{ }^{\prime} 22$ & 2.27 & 160 & 82 & $1.43^{2}$ & 4.5 & $6 \times 10^{11}$ & $1.5^{2}$ \\
\hline
\end{tabular}

${ }^{1}$ Applies only to vehicles with direct injection engines. ${ }^{2}$ Kept under annual review to reflect technological progress. $\mathrm{NM}=$ New models (month/year); $\mathrm{AM}=$ All models (month/year); $\mathrm{CF}=$ Conformity factor; $\mathrm{EDC}=$ European driving cycle; NEDC = New European driving cycle; WLTC $=$ Worldwide harmonized light vehicles test cycle.

Beginning with Euro 5 (adopted in 2009), standards are issued by Regulations, which are directly enforceable in all Member States, as opposed to Directives, which had to be transposed into each individual Member State. Note that the light-duty Euro standards use Arabic numerals, as opposed to heavy-duty Euro standards which use Roman numerals. All dates listed in the tables refer to new type approvals (TA). The EC Directives also specify a second date, usually one year later, which applies to first registration (FR-entry into service) of existing, previously type-approved vehicle models. The vehicle classes such as passenger cars (M1), small buses $<5000 \mathrm{~kg}$ (M2), light commercial vehicles $<3500 \mathrm{~kg}$ (N1), or larger ones 3500-12500 kg (N2) are described in Commission Directive 2001/116/EC. For Euro 3, and later the Category N1 reference, mass classes are Class I $\leq 1305$ kg, Class II 1305-1760 
$\mathrm{kg}$, and Class III $>1760 \mathrm{~kg}$. For Euro 1 and Euro 2 the Category N1 reference mass classes were Class I $\leq 1250 \mathrm{~kg}$, Class II 1250-1700 kg, and Class III > $1700 \mathrm{~kg}$.

\subsection{Test Cycles and Procedures}

Emissions were tested over the European driving cycle (EDC) or MVEG (motor vehicle emissions group) cycle (Euro 1 and Euro 2). Effective in 2000 with the Euro 3 standard, the cycle was modified to eliminate the 40 seconds engine warm-up period before the beginning of emission sampling. This modified cold start test is referred to as the New European Driving Cycle (NEDC).

Regulation 715/2007, which established the Euro 5 and 6 engine standards, stated that the [European] Commission should "keep under review the need to revise the New European Drive Cycle." In September 2017 the worldwide harmonized light vehicles test procedure (WLTP) and the corresponding worldwide harmonized light vehicles test cycle (WLTC) replaced the NEDC procedure for new car types (September 2018 for all new vehicles). The WLTC is based on real-world driving profiles and contains more dynamic driving conditions than the NEDC, such as higher maximum velocity and less idling time. The new testing procedure contains more differences than the speed profile alone, and these differences can be grouped in four categories [82]:

- Road load setting.

- Laboratory test set up and conditions.

- Post-processing of the test results.

- Declaration of $\mathrm{CO}_{2}$ results.

\subsection{Real-Driving Emissions (RDE)}

Despite the increasing stringency of the European emission standards, a series of studies, beginning in 2011 using portable emission measurement systems (PEMS) mounted onboard vehicles [83], as well as studies utilizing remote sensing techniques [84], reported unexpectedly high real-world emissions of nitrogen oxides $\left(\mathrm{NO}_{\mathrm{x}}\right)$ from European diesel passenger cars.

The gap between official laboratory results and the actual on-road emissions led to a revision of the emission type approval requirements in the EU. The use of PEMS and the introduction of the 'not-to exceed' (NTE) regulatory concept was based on Regulation 715/2007 where it was stated that revisions may be necessary to ensure that real world emissions correspond to the levels measured at type approval. A technical working group on real-driving emissions (RDE) was set up in 2011. The work of the RDE group produced several pieces of legislation: Commission Regulation (EU) 2016/427 (first regulatory act of the RDE regulation) introduced on-road testing with PEMS to complement the laboratory Type I test for the type approval of light-duty vehicles in EU. Subsequently, Commission Regulation (EU) 2016/646 introduced the NTE concept, which equals the emission limit for the laboratory Type I test multiplied by a so-called conformity factor (CF) that takes into account the measurement uncertainty of the PEMS. Both regulations were consolidated in the WLTP EC Regulation (EU) 2017/1151, and further developed by EC Regulation (EU) 2017/1154 (the third part of the RDE Regulations), which also introduced a RDE conformity factor for the on-road test of solid particle number (SPN) emissions. The fourth part of the RDE Regulation 2018/1832 introduced on-road emissions testing as part of in-service conformity checks and slightly lowered the conformity factor for $\mathrm{NO}_{\mathrm{x}}$ following a review [85].

The RDE test is performed during vehicle operation using a PEMS with SPN CF 1.5 from September 2017 for new models and from September 2018 for all new vehicles of types M, N1 and one year later N1-II, NI-III, and N2 vehicles. A temporary $\mathrm{CF}$ for $\mathrm{NO}_{x}$ was set at 2.1 and can be used upon the request of the manufacturer in Europe from September 2017 for new models and from September 2019 for all new vehicles. The final $\mathrm{CF}$ for $\mathrm{NO}_{\mathrm{x}}$ for January 2020 (new models) and 2021 (all new vehicles) was originally set at 1.5 and it was reduced, following a review, to 1.43 in 2018 [85].

It should be mentioned that the $\mathrm{NO}_{x}$ gap seen with the diesel vehicles was not an issue for gasoline vehicles in Europe [83,86]. However, this was questioned by a recent study in China [87]. 
The main concern for gasoline vehicles was the SPN emissions: would low SPN gasoline emissions in the laboratory be reflected also in real world?

\subsection{SPN-PEMS}

Regulation 459/2011 required the development of test procedures to measure particle emissions from PI vehicles under real driving conditions. The Commission was tasked with developing and introducing corresponding measurement procedures at the latest within three years after the enforcement of Euro 6. To address the SPN issue, JRC evaluated the efficacy of random dynamometer cycles or on-road testing with PEMS. PEMS was the preferable option, but the technology for measuring SPN on a vehicle was not as accurate as the one in the laboratory.

In November 2012 the interest for SPN-PEMS was announced and in April 2013 the kick-off meeting of SPN-PEMS group took place. The group worked intensively and continuously until the end of 2015. In a preliminary study, a theoretical evaluation was conducted and showed that diffusion charging (DCs) based instruments are an acceptable alternative to the condensation particle counters (CPCs) of the laboratory SPN PMP equipment, with an extra measurement uncertainty of $50 \%$ [88]. At a next step (end of 2013) various prototype SPN-PEMS (DC-based) were evaluated in a chassis dynamometer lab to assess and validate the application and performance of portable SPN instrumentation. The results showed that the best performing SPN-PEMS was within $60 \%$ compared to the reference laboratory PMP system. In the second evaluation phase (which started in September 2014 and lasted until the end of that year) the best performing SPN-PEMS (DC-based, the same as in Phase I) had differences from the reference instrument at the dilution tunnel within 50\% (with only a few exceptions) [89]. JRC selected the two best performing systems (one DC, and one CPC based) for the assessment of their performance through an interlaboratory comparison exercise (ILCE). The differences to the reference PMP systems were lower than 50\% [90].

At this point it should be clarified that the SPN (and $\mathrm{NO}_{\mathrm{x}}$ ) CF covers only the sampling and instrument measurement uncertainty. It is well known that the vehicle SPN emissions will vary from trip to trip based on the route, traffic, driving style, altitude, ambient temperature, fuel, etc. This variability is not deemed to be included in the CF and all emission levels measured over the RDE should be below the NTE limit.

\subsection{Market Surveillance}

Regulation (EU) 2018/858 replaced Directive 2007/46/EC and introduced a new EU type-approval framework (from September 2020), with an effective market surveillance system to control the conformity of vehicles already in circulation (from September 2019). Member states will be able to take measures (including ordering vehicle recalls and revoking type-approval certificates) against noncompliant vehicles sold in their national markets, instead of having to wait for the type-approval authority of the country that issued the vehicles' type-approval certificate to take action.

\section{Results}

The first section of the results presents trends in SPN, PM (Appendix A also presents total PN), and size distributions based on an exhaustive literature search on gasoline vehicles according to the criteria described in Section 5. The emissions are plotted separately for EU, US and Asia (China, Japan, Korea) type approved vehicles, when enough data are available. At each region the respective type approval cycles are used (e.g., FTP-75 or LA92 in US, JC08 in Japan, NEDC in EU until 2017, and WLTC from 2017 in EU). It must be repeated that all results refer to vehicles over transient driving cycles and not engines operating on specific steady-state modes, to better reflect actual operation emission levels. The studies considered for each group of results are given in Appendix B. With gasoline particulate filters (GPFs) becoming popular lately, vehicles equipped with GPF are plotted separately. 


\subsection{PM Mass Emissions}

Figure 1 shows the PM mass emissions for GDI and PFI vehicles. The PM mass limits are designated with the lines.

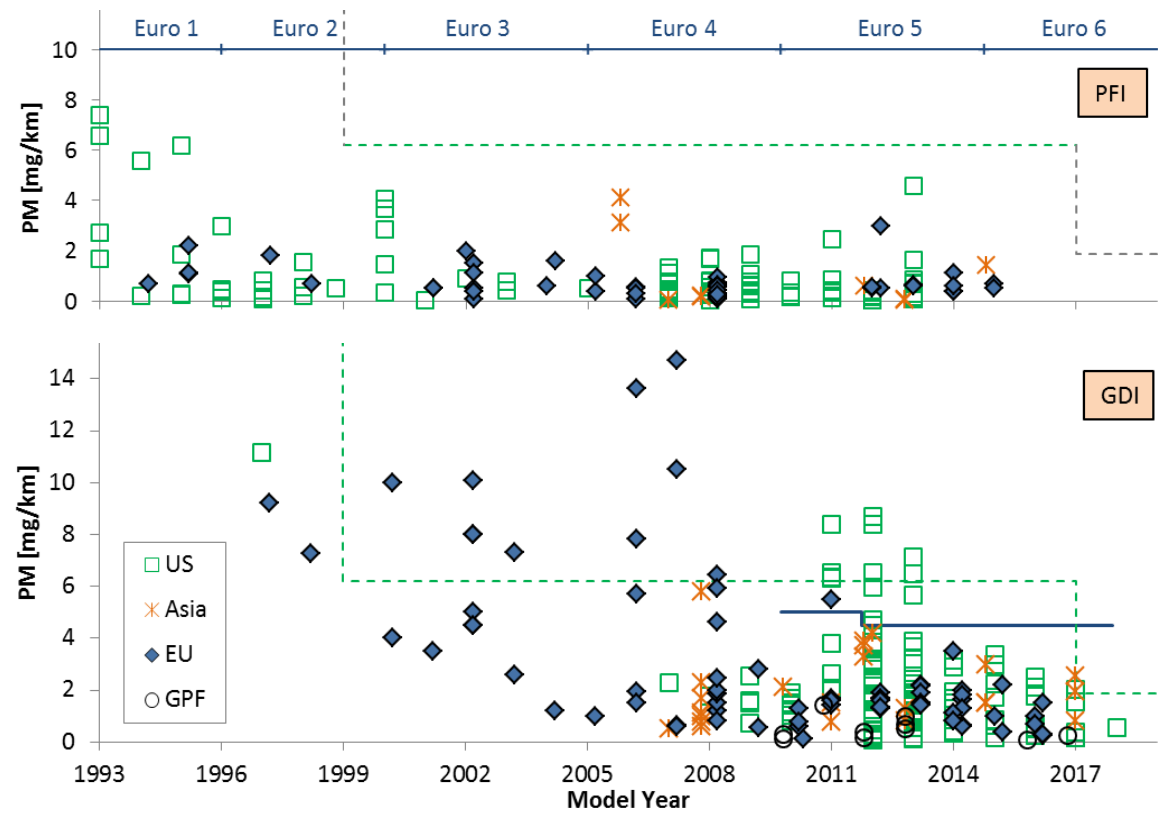

Figure 1. Particulate matter (PM) mass emissions for gasoline direct injection (GDI) (lower panel) and port fuel injection (PFI) (upper panel) vehicles. Solid line shows PM limits in EU for GDI vehicles. Dashed line shows the limits for gasoline vehicles (both GDI and PFI) in US.

The PM emissions of GDI vehicles (Figure 1, lower panel) clearly decreased over the years: from 4-14 mg/km (1996-2008) they dropped to <2 mg/km after 2009 in the EU. This does not have to do with the introduction of the PM limit, but with the introduction of the SPN limit, as it will be discussed later. The PM emissions in the US and Asia do not show a clear trend. The emissions are typically $<6 \mathrm{mg} / \mathrm{km}$ in the 25 years period shown; however there are some exceptions that have emissions from 6 to $8 \mathrm{mg} / \mathrm{km}$, probably due to the test cycles that were used (LA92 instead of FTP).

The PM mass emissions of PFI vehicles (Figure 1, upper panel) are low and typically $<2 \mathrm{mg} / \mathrm{km}$ for all regions. Higher emissions were measured for older vehicles (pre-2000) [91,92]. Some aggressive cycles, such as the Common Artemis Driving cycles (CADC), gave also emission levels around $10 \mathrm{mg} / \mathrm{km}$ (such cases not plotted in the figure). PM limits in the US were tightened from $6.2 \mathrm{mg} / \mathrm{km}$ (1999-2017, Tier 2) to $1.8 \mathrm{mg} / \mathrm{km}$ (from 2017, Tier 3). In California, a further reduction to $0.62 \mathrm{mg} / \mathrm{km}$ is phased-in starting 2025. Interestingly there are no PM data for US MY after 2013, probably due to the increased research interest on GDIs and their high market share. In China, a PM limit of $4.5 \mathrm{mg} / \mathrm{km}$ applies to GDI vehicles only, starting with China 5. The limit continues through China 6a (2020), and further tightens to $3 \mathrm{mg} / \mathrm{km}$ with China $6 \mathrm{~b}$ (2023).

\subsection{Chemical Composition}

PM emissions from PFI vehicles are generally very low to allow for an accurate characterization of their chemical composition. Under hot engine conditions, most of the emitted PM is elemental and organic carbon [93,94]. Studies in the early 2000s, where the PM levels were $\sim 0.5 \mathrm{mg} / \mathrm{km}$, found elemental carbon (EC) percentages of less than 30\% over NEDC cycles [95,96]. Engine studies found even lower EC fractions $(<5 \%)[97,98]$. EC can be higher under transient engine operation or at low ambient temperatures [99]. A US study found percentages of 30 to $65 \%$ (black carbon) over FTP cycles [100]. Another study reported that the EC fraction increased from $40 \%$ to $75 \%$ when the temperature decreased from $22^{\circ} \mathrm{C}$ to $-1{ }^{\circ} \mathrm{C}$ [101]. 
Most of the PM emitted by GDI vehicles is found to be EC (on average $80 \%$; range: $45-95 \%$ ). The high EC content is consistent since the introduction of GDIs in the markets: from early 2000s $[93,95]$ to 2010s [94,100,102-109]. The vehicle to vehicle variability masks any influence of test cycle, position of the injectors (side or top), or fuel injection strategy (stratified or stoichiometric) on the relative contribution of EC to PM. Engine studies have also shown high EC percentages (70-93\%) [98,110], but other studies have found much lower percentages $(15-35 \%)$ [111,112]. With dedicated engine studies it was also shown that idle or fuel cut conditions can increase the volatile part [110] and that the EC fraction is higher under lean stratified conditions (80\%) compared to stoichiometric (60\%) [113].

Other PM components are S, Fe, Ca, P, and Na $[97,98,110,114]$. Ash in the engine-out PM is mostly derived from lube oil additives $[98,110]$. Detachment of some support materials from the catalytic converter also contributes [110]. The ash that was found in a GPF after 240,000 km of driving consisted of approximately 50\% engine oil additive components ( $\mathrm{Ca}, \mathrm{P}, \mathrm{S}$, and $\mathrm{Zn}$ ), 20\% corrosion material (mainly $\mathrm{Fe}_{2} \mathrm{O}_{3}$ ), and 30\% catalytic washcoat from the three-way catalyst [65]. Polycyclic aromatic hydrocarbons (PAHs) can also be found in significant concentrations when there is no GPF [99-101,115-118]. PAHs are a concern because of their carcinogenicity and mutagenicity [119]. GPFs can reduce PAHs $>60 \%[115,120]$.

\subsection{SPN Emissions}

Figure 2 shows the SPN trends for GDI and PFI vehicles. EU has SPN limits only for GDI vehicles (shown with solid line), while the China 6 limits will apply to both GDI and PFI vehicles (starting 2020 , nationwide). Note that the SPN measurement protocol was established with the introduction of SPN limits for diesel vehicles (2011), thus measurements at earlier years were not always fully compliant with the protocol. Only measurements that used a thermal conditioning stage of at least $250{ }^{\circ} \mathrm{C}$ were considered in the results. Total PN (including volatiles and particles $<23 \mathrm{~nm}$ ) are discussed in Appendix A.

The decreasing trend of GDI emissions with time is clear (Figure 2, lower panel). The emissions were $>10^{13} \mathrm{p} / \mathrm{km}$ when GDIs were first widely introduced in the market [9]. A further reduction was noticed [121] with the introduction of stratified and spray-guided GDIs in 2006 [14]. The laboratory SPN limit of $6 \times 10^{11} \mathrm{p} / \mathrm{km}$ for the NEDC was achieved with a margin $\left(4.4 \times 10^{11} \mathrm{p} / \mathrm{km}\right)$ in 2011 only with in-cylinder measures [42,122] (shown as point in MY 2010.3). In 2014 it was reported that the limit could also be achieved with a prototype vehicle on the road at moderate driving [123]. However, with aggressive driving (many high load accelerations) the SPN emissions were higher than the limit. The first on-road evaluations with Euro 5 and Euro $6 \mathrm{~b}$ vehicles showed that the emissions remained below the $6 \times 10^{12} \mathrm{p} / \mathrm{km}$ limit $[124,125]$ and they were by a factor of two higher compared to the laboratory results [126]. Recently a commercial non-GPF GDI vehicle achieved emissions much lower than the SPN limit under normal driving conditions [127]. Non-GPF GDIs may achieve the RDE limit under mild conditions of use [128], although with high aromatic content fuel, severe conditions of testing, and low ambient temperature, the same vehicle may emit more than the RDE limit [129]. Another concern is the increase of emissions due to deterioration of the injectors [130].

The first GPF investigations were reported in 2011 [55]. While this was preceded by extensive experience with DPFs, the differences in operating conditions for the GPFs were highlighted: lower engine out SPN levels, higher exhaust gas temperatures, and lower oxygen concentration. Investigations included GPF porosity, pore size, cell structure, dimensions, position (closed-coupled or underfloor), and the presence and amount of catalytic coating $[23,58,60]$. Numerous researchers have since demonstrated the performance of GPFs, quantifying key metrics such as filtration efficiency, pressure drop, and gas conversion (for catalyzed filters) [23]. Several studies have also shown that the filtration efficiency only improves with mileage accumulation $[60,63,65,131]$. This is due to the accumulation of an ash layer on the channel walls, which prevents further penetration of soot particles [68]. The first commercial GPF equipped vehicle was introduced in the market in 2014 and was tested for particle emissions in 2016 [132]. The emissions were $<10^{11} \mathrm{p} / \mathrm{km}$ under all driving conditions. Analysis of 
type approval RDE data from September 2017 of $>340$ vehicles from the database of the European Automobile Manufacturers Association (ACEA) [133] and the Japan Automobile Manufacturers Association (JAMA) [134] gave a mean of $1.3 \times 10^{11} \mathrm{p} / \mathrm{km}$ and a median of $9.5 \times 10^{10} \mathrm{p} / \mathrm{km}$.

Figure 2 (upper panel) plots the emissions of PFI vehicles. There is no clear trend on the emissions over the last 25 years. Most of the results range between $1 \times 10^{11} \mathrm{p} / \mathrm{km}$ to $3 \times 10^{12} \mathrm{p} / \mathrm{km}$. What is rather surprising is that $31 \%$ of the EU sample have emissions $>6 \times 10^{11} \mathrm{p} / \mathrm{km}$. This percentage remains similar even if only vehicles after 2011 are considered (where a SPN limit was applicable to diesel vehicles). Recent on road tests with PFI vehicles (including hybrids) showed that the emissions are $<1 \times 10^{12} \mathrm{p} / \mathrm{km}[135-137]$.

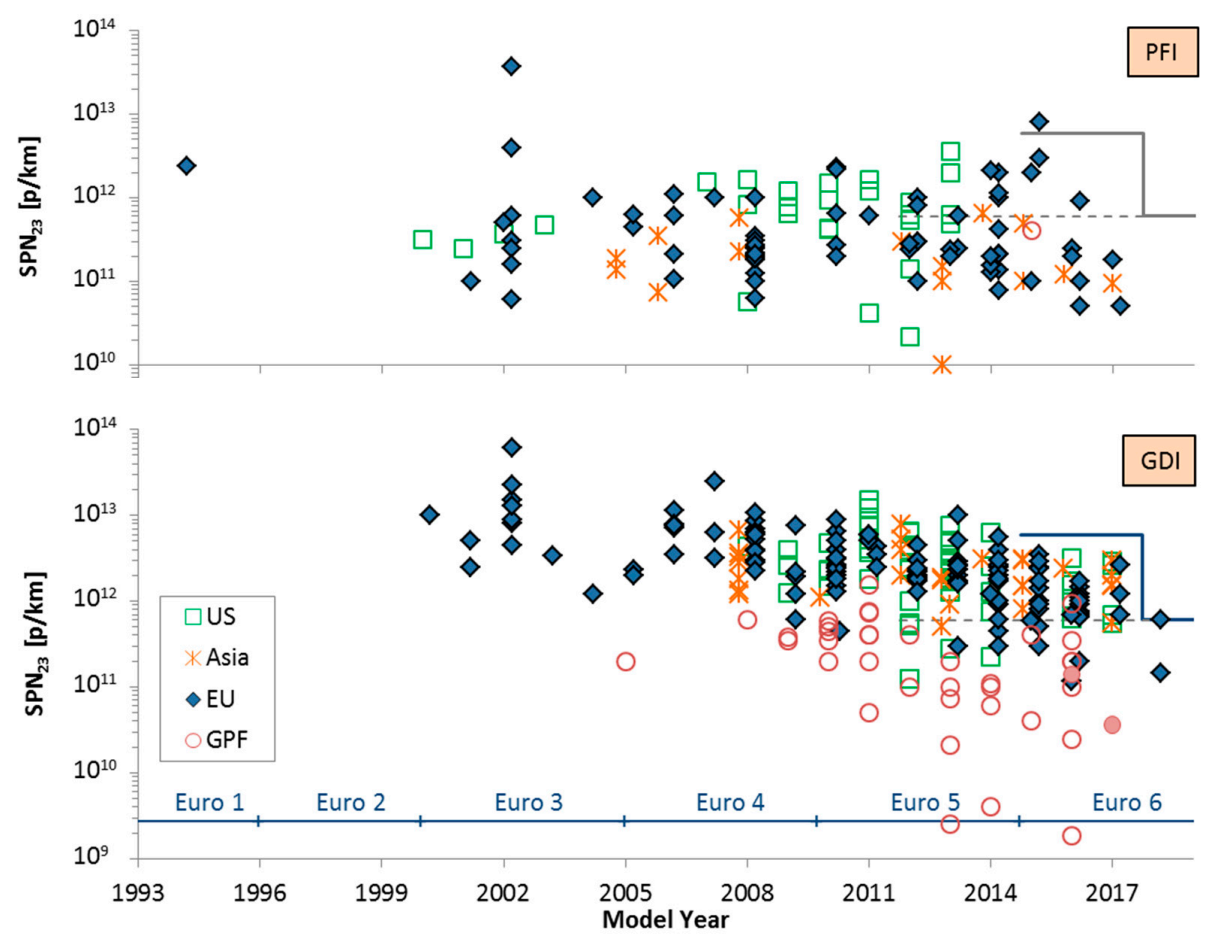

Figure 2. Solid particle number (SPN) emissions for gasoline direct injection (GDI) (lower panel) and port fuel injection (PFI) (upper panel) vehicles. Dashed line shows SPN limit for diesel vehicles (only EU). Solid line shows SPN limits for GDI vehicles (only EU). The solid circles are commercial GPF equipped vehicles (open circles are GPF retrofitted vehicles).

\subsection{Size Distributions}

Figure 3 summarizes the GMDs (geometric mean diameters) of GDIs and PFIs with or without thermal pretreatment of the sampled particles. Each point is the reported mean of a vehicle over the type approval cycle, typically measured with size spectrometers such as EEPS (Engine Exhaust Particle Sizer), DMS (Differential Mobility Spectrometer), and ELPI (Electrical Low Pressure Impactor) [79]. The "solid" size distributions were measured downstream of a thermodenuder or a catalytic stripper heated at temperatures $>250{ }^{\circ} \mathrm{C}$ [79]. The pre-2005 GDI vehicles have GMDs of solid particle size distributions between 60 and $90 \mathrm{~nm}$ and the PFIs between 45 and $90 \mathrm{~nm}$. The post-2008 vehicles have GMDs of solid particle size distributions between 25 and $70 \mathrm{~nm}$ and the PFIs between 20 and $60 \mathrm{~nm}$. The shift downwards is probably linked with improved combustion and charge mixing. Boosted engines have been shown to produce particles with smaller sizes [24]. While at the same time the particle number concentrations were reduced, the smaller sizes below approximately $30 \mathrm{~nm}$ have higher deposition fraction in the lungs [138]. The GMDs of total particles size distributions are slightly wider extending to smaller sizes because the (additional) volatile nucleation mode decreases the GMD. 
The calculated average geometric standard deviation (GSD) of GDIs was 1.9 and of PFIs 2.0, in good agreement with those reported by others [139].

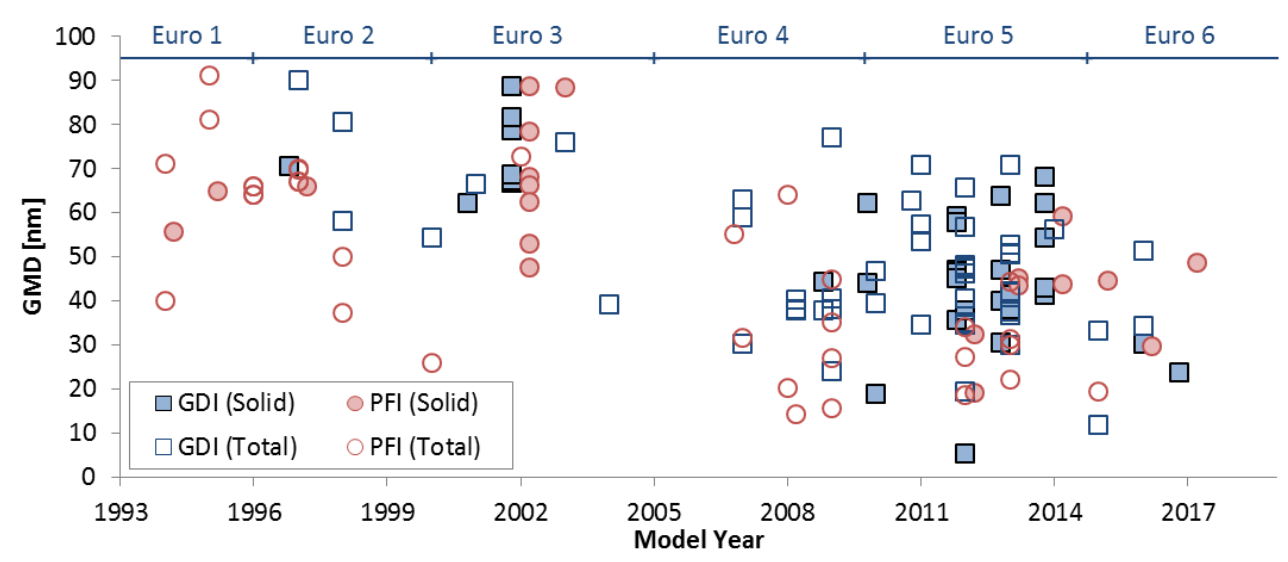

Figure 3. Geometric mean diameter (GMD) of solid and total (solid + volatiles) size distributions for gasoline direct injection (GDI) and port fuel injection (PFI) vehicles. Results from all regions (EU, US, and Asia).

\subsection{Transmission Electron Microscopy (TEM) Studies}

Transmission electron microscopy (TEM) can be used to provide information regarding the shape and structure of the particles collected. Energy dispersive spectrometry (EDS) can provide their elemental composition. The first TEM image of an agglomerated soot particle of a GDI vehicle at constant speed was shown in 2004 [140]. The primary particles diameter was $28 \pm 3 \mathrm{~nm}$. Later studies with GDI engines found that primary particles were distributed over a range of 7 to $60 \mathrm{~nm}$ in diameter $[71,111,141]$. For early fuel injection strategy, the primary particle diameter was between 20 and $25 \mathrm{~nm}$ with graphitic structure. For a fuel injection strategy, which produced low particle number concentration, there were many single solid sub- $25 \mathrm{~nm}$ particles and fractal like agglomerates with primary particle size between 10 and $15 \mathrm{~nm}$ with more amorphous structure. Later it was shown that the primary particle size correlated with the aggregate size [142]. Other studies found primary particle sizes between 20 to $30 \mathrm{~nm}$ [143-148]. Recent studies with GDI vehicles, in addition to soot particles, also found oil derived ash particles in the size range of 10-25 nm [149,150], emitted, e.g., during engine braking [151].

\subsection{Low Ambient Temperature}

Figure 4 plots the PM mass emission of GDI (diamonds) and PFI (circles) vehicles at ambient temperatures of $\sim 23{ }^{\circ} \mathrm{C}$ (solid symbols) and $-7^{\circ} \mathrm{C}$ (open symbols) tested in the laboratory under type approval cycles. In all cases there is an increase of the PM mass at lower temperature. For PFIs, the increase was small in some instances $(+1 \mathrm{mg} / \mathrm{km})$, while in others it was quite high, leading to $\mathrm{PM}$ emissions in the 8 to $12 \mathrm{mg} / \mathrm{km}$ range. For GDIs the $-7^{\circ} \mathrm{C}$ tests resulted in PM mass $>5 \mathrm{mg} / \mathrm{km}$, with one vehicle at $14 \mathrm{mg} / \mathrm{km}$. Only the GDI retrofitted with a GPF kept the PM mass below the $2 \mathrm{mg} / \mathrm{km}$ level.

Figure 5 plots the SPN emissions of PFIs (triangles, upper panel) and GDIs (diamonds or circles when equipped with GPF, lower panel) at ambient temperatures of around $23^{\circ} \mathrm{C}$ (solid symbols) and $-7^{\circ} \mathrm{C}$ (open symbols). Similar to mass emissions described above, the SPN emissions consistently increased when the test was conducted at $-7^{\circ} \mathrm{C}$. For emission levels above $1 \times 10^{12} \mathrm{p} / \mathrm{km}$ at $23^{\circ} \mathrm{C}$ the emissions on average doubled at $-7^{\circ} \mathrm{C}$ [152]; however, for lower emission levels they increased up to 3-4 times. While none of the Euro 6 vehicles exceeded the $6 \times 10^{12} \mathrm{p} / \mathrm{km} \mathrm{limit}$, all exceeded $6 \times 10^{11} \mathrm{p} / \mathrm{km}$ at $-7^{\circ} \mathrm{C}$. For those GDIs that were equipped with GPF, their tailpipe emissions did 
not significantly increase at the $-7^{\circ} \mathrm{C}$ tests and they remained below the $6 \times 10^{11} \mathrm{p} / \mathrm{km}$ limit $(\mathrm{MY}$ after 2011).

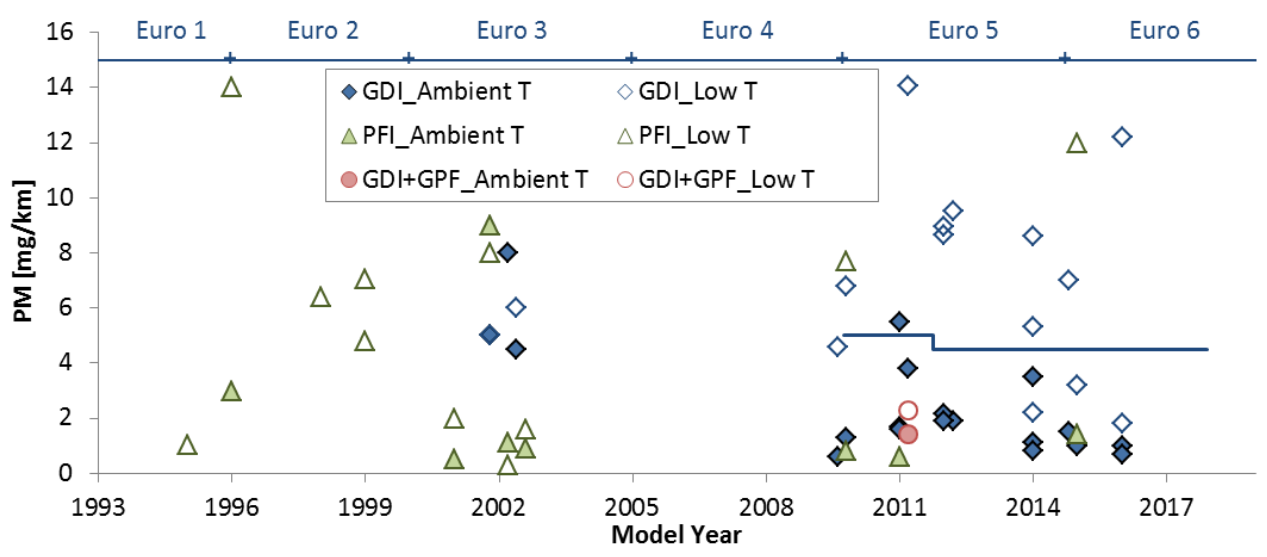

Figure 4. Particulate matter (PM) mass emissions for gasoline direct injection (GDI) (lower panel) and port fuel injection (PFI) (upper panel) vehicles at different ambient temperatures. "Ambient $\mathrm{T}^{\prime \prime}$ refers to approximately $23^{\circ} \mathrm{C}$. “Low T" refers to $-7^{\circ} \mathrm{C}$. Solid line shows PM limits for GDI vehicles at $23^{\circ} \mathrm{C}$ (only EU).
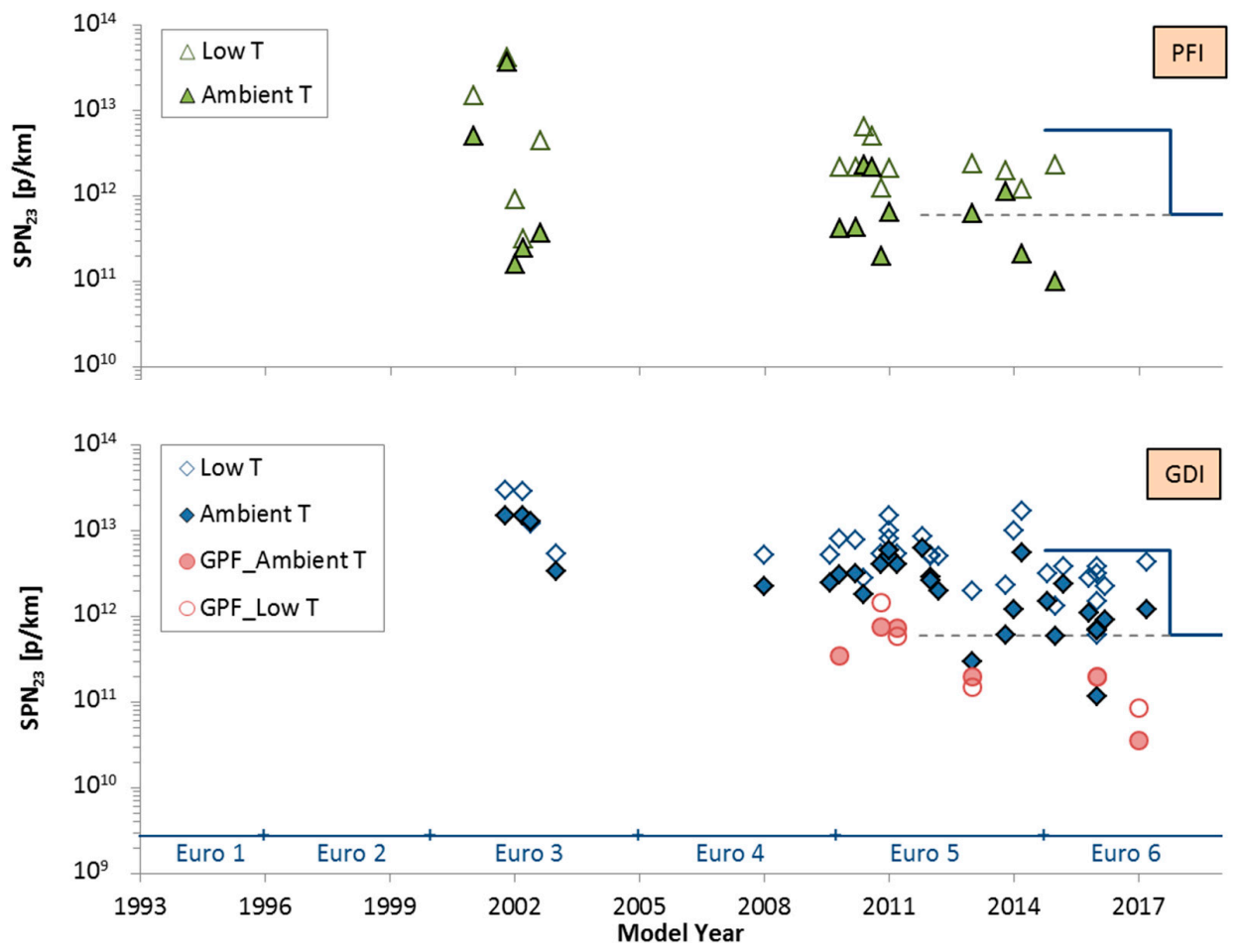

Figure 5. Solid particle number (SPN) emissions for gasoline direct injection (GDI) (lower panel) and port fuel injection (PFI) (upper panel) vehicles at different ambient temperatures. "Ambient $\mathrm{T}^{\text {" refers to }}$ approximately $23^{\circ} \mathrm{C}$. "Low $\mathrm{T}^{\prime}$ r refers to $-7^{\circ} \mathrm{C}$. Dashed line shows SPN limit for diesel vehicles at $23^{\circ} \mathrm{C}$ (only EU). Solid line shows SPN limits for GDI vehicles at $23^{\circ} \mathrm{C}$ (only EU).

Currently, gasoline vehicles have limits for $\mathrm{CO}$ and $\mathrm{HCs}$ at $-7^{\circ} \mathrm{C}$. Discussions are ongoing to introduce a low temperature procedure in the regulations. The results of the two figures can support in deciding future limits. 


\subsection{Sub-23 nm Fraction}

Figure 6 summarizes the results of studies that measured (solid) particles sized below $23 \mathrm{~nm}$, which is currently the lower size limit defined in the EU regulation. Additionally, based on the size distributions of solid particles shown in Figure 3, the fraction of particles below $23 \mathrm{~nm}$ was estimated assuming a lognormal distribution and was added in Figure 6. The assumption of monomodal size distributions is not necessarily true and underestimates the cases with a separate nucleation mode. Until early 2000s, there are only estimations of the particle number fraction below $23 \mathrm{~nm}$. Due to the large GMD, this fraction is found to be below $15 \%$ of the total number. The estimated percentage after 2009 raises up to $45 \%$ for both GDIs and PFIs (one 2012 GDI estimated at close to 100\%). The measured percentage for GDIs is in the same range with a few measurements in the 45 to $60 \%$ range. However, for PFIs the measured percentage is up to $75 \%$ ( $95 \%$ in one case).

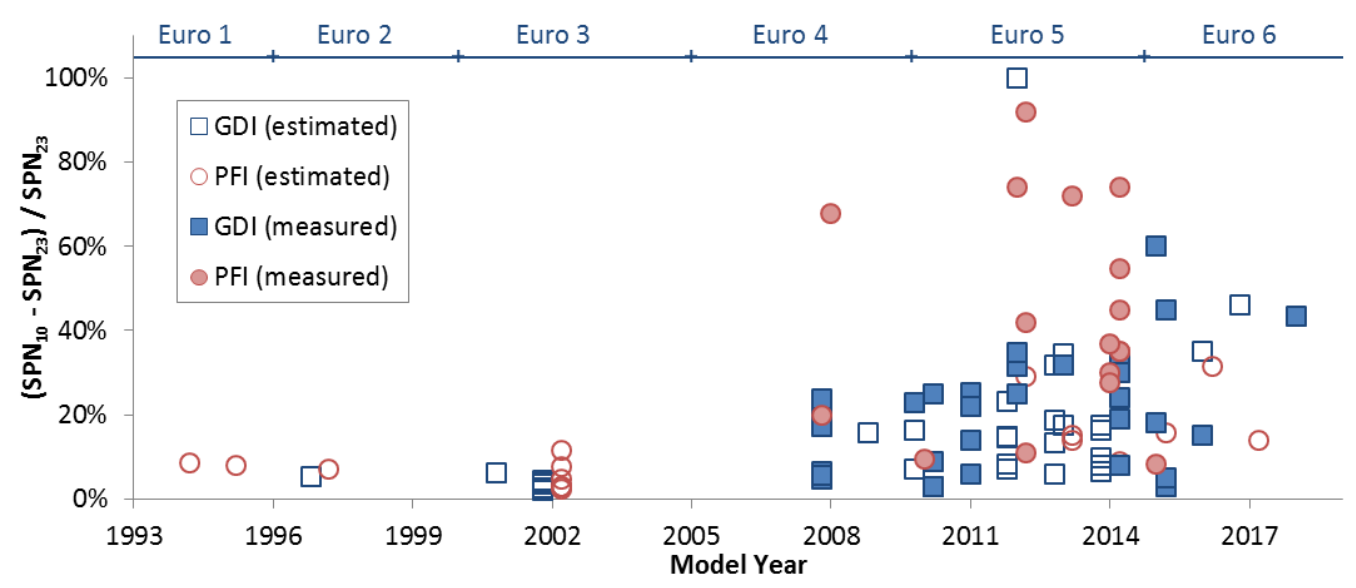

Figure 6. Additional particles below $23 \mathrm{~nm}$. Measured: Based on $23 \mathrm{~nm}$ and $10 \mathrm{~nm}$ condensation particle counters (CPCs) downstream of a thermal pretreatment unit. Estimated: Based on solid size distributions (Figure 3). No corrections for particle losses in the measurement systems.

Figure 7 plots the ratio of particles above over below $23 \mathrm{~nm}$ as a function of the emission levels following the regulatory method $\left(\mathrm{SPN}_{23}\right)$. Generally, there is a tendency of a higher percentage with lower emissions. This is an indication that for high concentrations coagulation takes place and increases the GMD [153]. In addition, the relative contribution of lubricant increases as soot from combustion decreases. The percentage can be $>30 \%$ for emission levels $<1 \times 10^{12} \mathrm{p} / \mathrm{km}$.

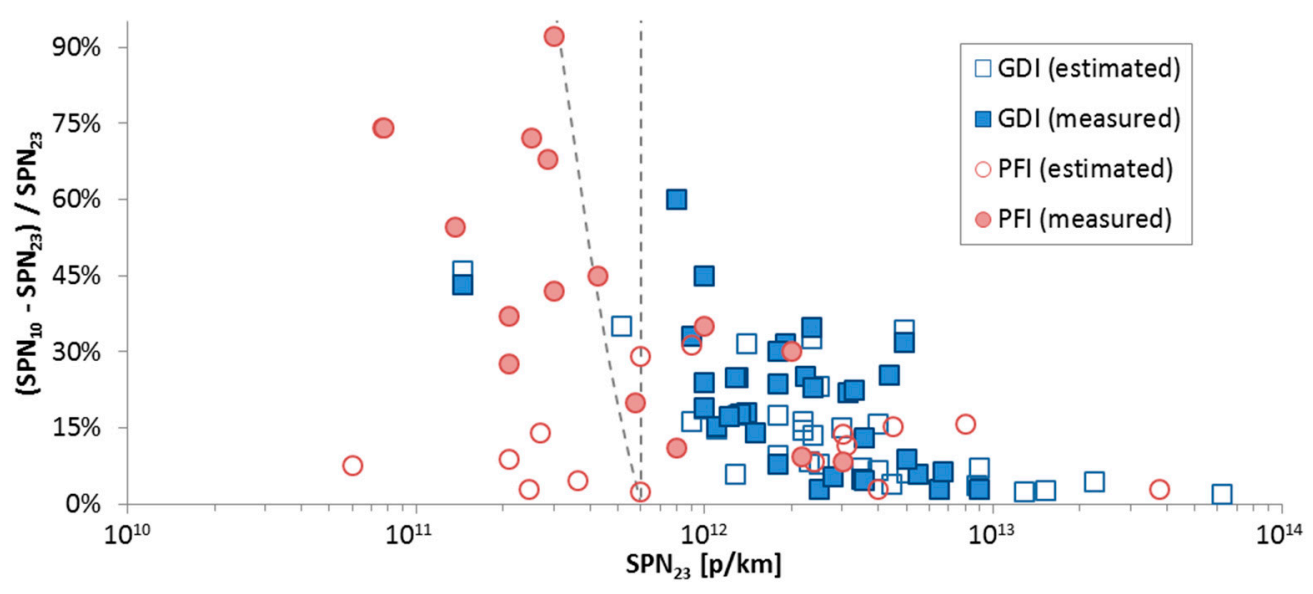

Figure 7. Additional particles below $23 \mathrm{~nm}$ as a function of the emission levels of particles $>23 \mathrm{~nm}$. Measured: Based on $23 \mathrm{~nm}$ and $10 \mathrm{~nm}$ condensation particle counters (CPCs) downstream of a thermal pretreatment unit. Estimated: Based on solid particle size distributions (Figure 3). No corrections for particle losses. Dashed lines show the $6 \times 10^{11} \mathrm{p} / \mathrm{km}$ limit for $23 \mathrm{~nm}$ (vertical) and $10 \mathrm{~nm}$ (diagonal). 
Keeping the same limit $6 \times 10^{11} \mathrm{p} / \mathrm{km}$ but changing the lower size from $23 \mathrm{~nm}$ to $10 \mathrm{~nm}$ would result in 2 out of 15 measured cases failing the new methodology. Thus, the current SPN methodology can still identify most, but not all, high emitting gasoline vehicles. The number of cases would increase with a lower limit, for example $3 \times 10^{11} \mathrm{p} / \mathrm{km}$. In any case, when the fraction of total emissions not measured with the current methodology is significant, decreasing the threshold below $23 \mathrm{~nm}$ would provide a more comprehensive control of future gasoline vehicle emissions.

\section{Materials and Methods}

The analysis and the graphs of this study are based on a literature survey on particle emissions of gasoline vehicles using relevant terms (gasoline, direct injection, port fuel, multipoint injection, GDI, DISI, MPI, PFI, particulate emissions, particle number, size distribution, and TEM) and in addition scanning the references cited therein. The vehicles had to be type approved according to the Euro 1 emission standards or the model year (MY) had to be 1993 or later.

Only vehicle studies were considered. Only results with market or reference fuels with ethanol content up to $10 \%$ were used. Studies with addition of additives, oils etc. in the fuel were not included. For the solid particle number (SPN) analysis (total or GMD) only studies following the regulated procedure, or using thermodenuder, or catalytic stripper with temperature $>250{ }^{\circ} \mathrm{C}$ were analyzed. For total particle size distributions only studies without any thermal pretreatment were accepted (i.e., dilution with air at ambient temperature). The GMD was estimated by digitally replotting the size distributions from the relevant studies. Similarly, for the particle number emissions when the studies did not report the values in the text, the values were extracted digitally from the plotted figures so some uncertainty based on the resolution can be expected.

When enough data was available the results were split in the EU, US and Asia type approved vehicles. When the model year (MY) of the vehicle was not given it was assumed to be 1-2 years before the specific publication or based on the standard it followed. For the graphs the MYs were shifted \pm 0.2 years randomly to improve the readability.

The studies that were used in each figure are given in the Appendix B.

\section{Conclusions}

Emissions of gaseous pollutants from gasoline vehicles have been controlled since the 1970s. Significant reductions were achieved with the introduction of three-way catalysts in the 1990s. Particulate matter emissions were not considered an issue, because they were orders of magnitude lower than from diesel vehicles. The picture changed when particulate filters were installed on diesel vehicles and gasoline direct injection (GDI) vehicles were introduced in the market. The introduction of a solid particle number limit for the GDIs resulted in a significant decrease of their particulate emissions in terms of mass, solid, and total particle number concentrations. The new additional legislation requirement of achieving the same levels also on the road under real driving conditions resulted in installation of particulate filters for GDIs in EU models. Data included here showed that in some cases, emissions levels from PFI vehicles can exceed those from GDI vehicles. The low ambient temperature conditions further increase the emissions. The measured particle concentration below $23 \mathrm{~nm}$ is in many cases $>50 \%$ (without correcting for particle losses). These results suggest that for post Euro 6 regulations, assuming that PFIs still have an important market share, they should be included in the next regulatory step, the lower limit of $23 \mathrm{~nm}$ should be decreased to $10 \mathrm{~nm}$ and low ambient temperature tests for SPN should be included.

Author Contributions: Conceptualization, B.G. and P.D.; formal analysis, B.G.; writing—original draft preparation, B.G. and A.J.; writing-review and editing, L.N. and P.D.

Funding: This research received no external funding.

Conflicts of Interest: B.G., L.N., and P.D. declare no conflict of interest. A.J. is employed by Corning Incorporated which is supplier of particulate filters. 
Disclaimer: The opinions expressed in this manuscript are those of the authors and should in no way be considered to represent an official opinion of the European Commission. Mention of trade names or commercial products does not constitute endorsement or recommendation by the authors or the European Commission.

\section{Appendix A}

Figure A1 plots the total PN emissions for GDI (lower panel) and PFI (upper panel) vehicles. Different instruments were used (such as CPCs or EEPS) with different lower cut-off sizes (typically 2.5-6 nm). The majority of the measurements was conducted from the full dilution tunnel (CVS) where the dilution factor changes over a test. As with SPN, a decreasing trend can be seen for GDIs, but no trend for PFIs. As discussed elsewhere, the reproducibility of total PN measurements from the CVS is not good due to the variant dilution factor, the different flow rates employed at CVS, and the different residence times. In addition, the volatiles desorption from the transfer tubes to the CVS during high speed or aggressive cycles can result in unrealistically high values [107]. The opinion of the authors is that total PN should be conducted from the tailpipe under well-defined sampling conditions [154-156].

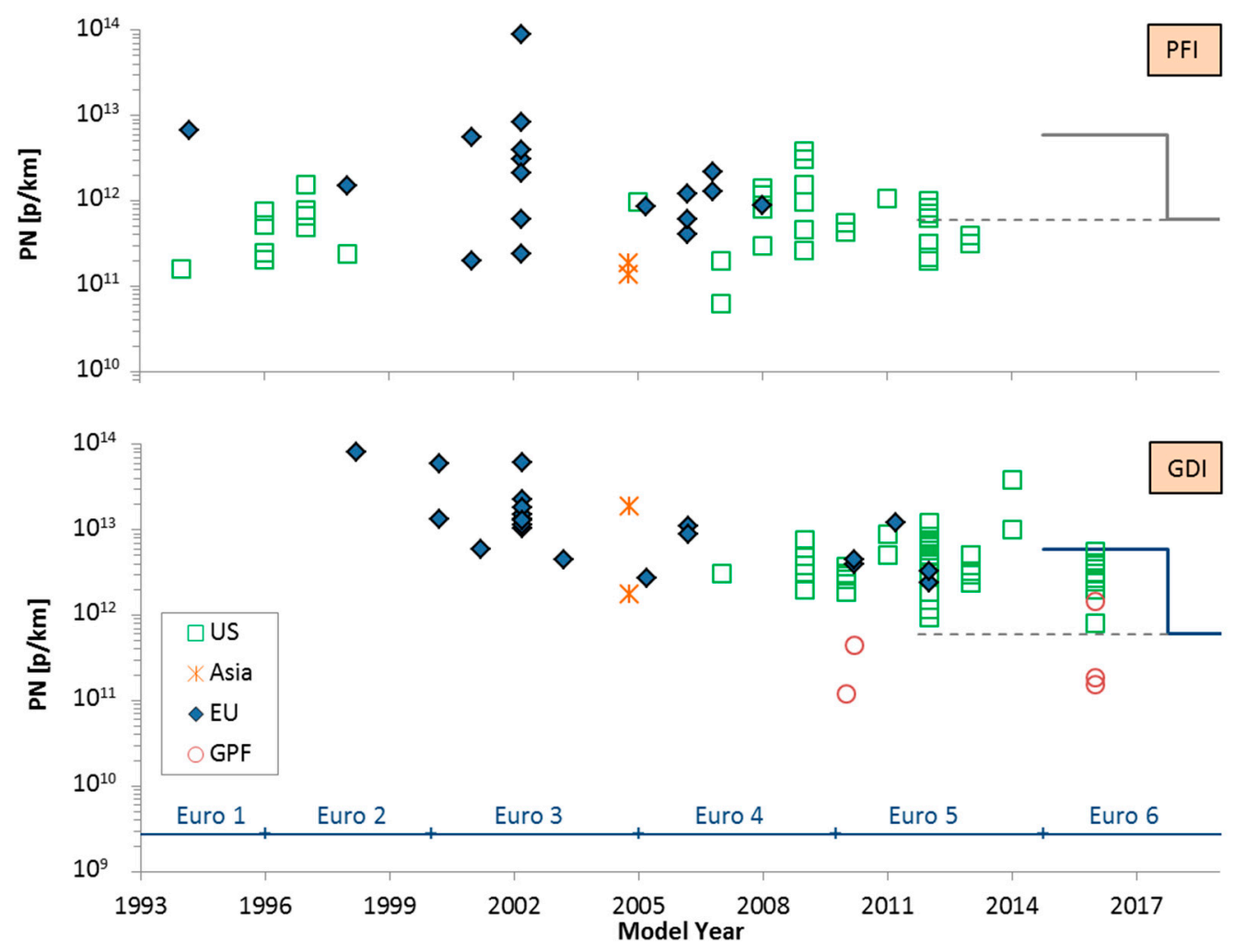

Figure A1. Total particle number (PN) emissions for gasoline direct injection (GDI) (lower panel) and port fuel injection (PFI) (upper panel) vehicles. Dashed line shows solid PN (SPN) limit for diesel vehicles (only EU). Solid line shows SPN limits for GDI vehicles (only EU).

\section{Appendix B}

The following studies were considered in the figures of the main text.

Figure 1 (upper panel): PM PFI: [42,91,93-96,100,101,121,157-194]

Figure 1 (lower panel): PM GDI: [37,42,51,68,74,93-95,100,102-106,108,109,120,121,132,157-163, $165-167,169,170,173,175-179,181,184,186,188-190,194-225]$

Figure 2 (upper panel): SPN PFI: [42,51,75,93,96,121,127,158-165,168-183,194,224,226-242]

Figure 2 (lower panel): SPN GDI: [18,42,53,55,56,58,60,61,63,68,74,75,93,103-105,109,114,115,120$124,126,127,132,137,150,158-165,169-171,173,175-181,194,197-203,205-209,211,214,218,222-226,228$, 230-235,237-241,243-258]

Figure 3: GMD (Solid): $[18,75,89,105,127,137,150,157,158,168,205,223,229,230,245,247,248,259-262]$ 
Figure 3: GMD (Total): [56,94,95,102,104,109,121,140,165-168,170,172,175,176,178,181,184,189,195, $198,204,210,212,213,231,236,237,254,263-271]$

Figure 4: Low temperature PM: [99,158,163,165,169,176,192,196,211,224,225]

Figure 5: Low temperature SPN: [60,75,158,163,165,169,176,196,201,211,224-226,234,240,257]

Figure 6: Sub-23 nm (measured): [18,75,127,163,177,223,247,248]

Figure 6: Sub-23 nm (estimated): As Figure 3: GMD (Solid).

Figure 7: As Figure 6.

Figure A1: Total PN [93,95,104,105,108,109,150,158,161-163,170,195,204,212,226,248,271-274]

\section{References}

1. European Commission. A Roadmap for Moving to a Competitive Low Carbon Economy in 2050; European Commission: Brussels, Belgium, 2011.

2. European Commission. Roadmap to a Single European Transport Area-Towards a Competitive and Resource Efficient Transport System; European Commission: Brussels, Belgium, 2011.

3. Javid, R.; Nejat, A.; Hayhoe, K. Selection of $\mathrm{CO}_{2}$ mitigation strategies for road transportation in the United States using a multi-criteria approach. Renew. Sustain. Energy Rev. 2014, 38, 960-972. [CrossRef]

4. Gambhir, A.; Tse, L.K.C.; Tong, D.; Martinez-Botas, R. Reducing China's road transport sector $\mathrm{CO}_{2}$ emissions to 2050: Technologies, costs and decomposition analysis. Appl. Energy 2015, 157, 905-917. [CrossRef]

5. Alkidas, A.C. Combustion advancements in gasoline engines. Energy Convers. Manag. 2007, 48, 2751-2761. [CrossRef]

6. Meinig, U. One hundred years of gasoline direct injection: Part 1. MTZ Worldw. 2016, 77, 60-66. [CrossRef]

7. Meinig, U. One hundred years of gasoline direct injection: Part 2. MTZ Worldw. 2016, 77, 30-37. [CrossRef]

8. Eastwood, P. Particulate Emissions from Vehicles; Wiley-Professional engineering publishing series; Wiley: Chichester, UK, 2008; ISBN 978-0-470-72455-2.

9. Iwamoto, Y.; Noma, K.; Nakayama, O.; Yamauchi, T.; Ando, H. Development of gasoline direct injection engine. SAE Trans. 1997, 106, 970541.

10. Mock, P. European Vehicle Market Statistics: Pocketbook 2018/19; International Council on Clean Transportation Europe: Berlin, Germany, 2018.

11. Davis, S.C.; Williams, S.E.; Boundy, R.G.; Moore, S.A. 2016 Vehicle Technologies Market Report; Oak Ridge National Lab.: Oak Ridge, TN, USA, 2017.

12. Hula, A.; French, R.; Maguire, A.; Bunker, A.; Rojeck, T. The 2018 EPA Automot. Trends Report: Greenhouse Gas Emissions, Fuel Economy, and Technol. since 1975; EPA-420-R-19-002; The Transportation Research Board: Washington, DC, USA, 2019.

13. Van Basshuysen, R.; Spicher, U. (Eds.) Gasoline Engine with Direct Injection: Processes, Systems, Development, Potential, 1st ed.; MTZ; Vieweg + Teubner: Wiesbaden, Germany, 2009; ISBN 978-3-8348-0670-3.

14. Zhao, H. (Ed.) Gasoline and Gas Engines; Advanced Direct Injection Combustion Engine Technologies and Development; Woodhead: Cambridge, UK, 2010; ISBN 978-1-84569-389-3.

15. Agarwal, A.K.; Dhar, A.; Sharma, N.; Shukla, P.C. Engine Exhaust Particulates; Springer: Singapore, 2019; ISBN 9789811332999.

16. Boger, T.; Cutler, W. Reducing Particulate Emissions in Gasoline Engines; SAE International: Warrendale, PA, USA, 2019; ISBN 978-0-7680-9417-6.

17. Zhao, F; Lai, M.-C.; Harrington, D.L. Automotive spark-ignited direct-injection gasoline engines. Prog. Energy Combust. Sci. 1999, 25, 437-562. [CrossRef]

18. Giechaskiel, B.; Manfredi, U.; Martini, G. Engine exhaust solid sub-23 nm particles: I. literature survey. SAE Int. J. Fuels Lubric. 2014, 7, 950-964. [CrossRef]

19. Myung, C.L.; Ko, A.; Park, S. Review on characterization of nano-particle emissions and PM morphology from internal combustion engines: Part 1. Int. J. Automot. Technol. 2014, 15, 203-218. [CrossRef]

20. Guan, B.; Zhan, R.; Lin, H.; Huang, Z. Review of the state-of-the-art of exhaust particulate filter technology in internal combustion engines. J. Environ. Manag. 2015, 154, 225-258. [CrossRef]

21. Überall, A.; Otte, R.; Eilts, P.; Krahl, J. A literature research about particle emissions from engines with direct gasoline injection and the potential to reduce these emissions. Fuel 2015, 147, 203-207. [CrossRef] 
22. Fang, T.; Wang, L.; Wang, Z. Particulate matter emissions from gasoline direct injection engines: Research review. J. Automot. Saf. Energy 2017, 8, 226-238.

23. Joshi, A.; Johnson, T. Gasoline particulate filters-A review. Emiss. Contr. Sci. Technol. 2018, 4, $219-239$. [CrossRef]

24. Raza, M.; Chen, L.; Leach, F.; Ding, S. A review of particulate number (PN) emissions from gasoline direct injection (GDI) engines and their control techniques. Energies 2018, 11, 1417. [CrossRef]

25. Shuai, S.; Ma, X.; Li, Y.; Qi, Y.; Xu, H. Recent progress in automotive gasoline direct injection engine technology. Automot. Innov. 2018, 1, 95-113. [CrossRef]

26. Duleep, K.G. The Impact of Gasoline Direct Injection System Design on PM Emissions; SAE Technical Paper: Warrendale, PA, USA, 2019.

27. Qian, Y.; Li, Z.; Yu, L.; Wang, X.; Lu, X. Review of the state-of-the-art of particulate matter emissions from modern gasoline fueled engines. Appl. Energy 2019, 238, 1269-1298. [CrossRef]

28. Johnson, T. Vehicular emissions in review. SAE Int. J. Engines 2012, 5, 216-234. [CrossRef]

29. Johnson, T. Vehicular emissions in review. SAE Int. J. Engines 2013, 6, 699-715. [CrossRef]

30. Johnson, T. Vehicular emissions in review. SAE Int. J. Engines 2014, 7, 1207-1227. [CrossRef]

31. Johnson, T. Review of vehicular emissions trends. SAE Int. J. Engines 2015, 8, 1152-1167. [CrossRef]

32. Johnson, T. Vehicular emissions in review. SAE Int. J. Engines 2016, 9, 1258-1275. [CrossRef]

33. Johnson, T.; Joshi, A. Review of Vehicle Engine Efficiency and Emissions; SAE Technical Paper: Warrendale, PA, USA, 2017.

34. Johnson, T.; Joshi, A. Review of Vehicle Engine Efficiency and Emissions; SAE Technical Paper: Warrendale, PA, USA, 2018.

35. Joshi, A. Review of Vehicle Engine Efficiency and Emissions; SAE Technical Paper: Warrendale, PA, USA, 2019.

36. Ikoma, T.; Abe, S.; Sonoda, Y.; Suzuki, H.; Suzuki, Y.; Basaki, M. Development of V-6 3.5-Liter Engine Adopting New Direct Injection System; SAE Technical Paper: Warrendale, PA, USA, 2006.

37. Fanick, R.; Kroll, S.; Swarts, A.; Quarderer, S. Effects of Dual Port Injection and Direct-Injection Technology on Combustion Emissions from Light-Duty Gasoline Vehicles; SAE Technical Paper: Warrendale, PA, USA, 2019.

38. Bock, N.; Jeon, J.; Kittelson, D.; Northrop, W.F. Solid Particle Number and Mass Emissions from Lean and Stoichiometric Gasoline Direct Injection Engine Operation; SAE Technical Paper: Warrendale, PA, USA, 2018.

39. Philipp, S.; Hoyer, R.; Adam, F.; Eckhoff, S.; Wunsch, R.; Schoen, C.; Vent, G. Exhaust Gas Aftertreatment for Lean Gasoline Direct Injection Engines_Potential for Future Applications; SAE Technical Paper: Warrendale, PA, USA, 2013; Volume 5.

40. Parks, J.E.; Storey, J.M.E.; Prikhodko, V.Y.; Debusk, M.M.; Lewis, S.A. Filter-Based Control of Particulate Matter from a Lean Gasoline Direct Injection Engine; AE Technical Paper: Warrendale, PA, USA, 2016.

41. Shelef, M.; McCabe, R.W. Twenty-five years after introduction of automotive catalysts: What next? Catal. Today 2000, 62, 35-50. [CrossRef]

42. Piock, W.; Hoffmann, G.; Berndorfer, A.; Salemi, P.; Fusshoeller, B. Strategies towards meeting future particulate matter emission requirements in homogeneous gasoline direct injection engines. SAE Int. J. Engines 2011, 4, 1455-1468. [CrossRef]

43. Velji, A.; Yeom, K.; Wagner, U.; Spicher, U.; Rossbach, M.; Suntz, R.; Bockhorn, H. Investigations of the Formation and Oxidation of Soot Inside a Direct Injection Spark Ignition Engine Using Advanced Laser-Techniques; SAE Technical Paper: Warrendale, PA, USA, 2010.

44. Karlsson, R.B.; Heywood, J.B. Piston Fuel Film Observations in an Optical Access GDI Engine; SAE Technical Paper: Warrendale, PA, USA, 2001.

45. Bock, N.; Jeon, J.; Kittelson, D.; Northrop, W. Effects of Fuel Properties on Particle Number and Particle Mass Emissions from Lean and Stoichiometric Gasoline Direct Injection Engine Operation; SAE Technical Paper: Warrendale, PA, USA, 2019.

46. Berndorfer, A.; Breuer, S.; Piock, W.; Von Bacho, P. Diffusion Combustion Phenomena in GDi Engines Caused by Injection Process; SAE Technical Paper: Warrendale, PA, USA, 2013.

47. Xu, H.; Wang, C.; Ma, X.; Sarangi, A.K.; Weall, A.; Krueger-Venus, J. Fuel injector deposits in direct-injection spark-ignition engines. Prog. Energy Combust. Sci. 2015, 50, 63-80. [CrossRef]

48. Jiang, C.; Xu, H.; Srivastava, D.; Ma, X.; Dearn, K.; Cracknell, R.; Krueger-Venus, J. Effect of fuel injector deposit on spray characteristics, gaseous emissions and particulate matter in a gasoline direct injection engine. Appl. Energy 2017, 203, 390-402. [CrossRef] 
49. Larsson, T.; Stenlaas, O.; Erlandsson, A. Future Fuels for DISI Engines: A Review on Oxygenated, Liquid Biofuels; SAE Technical Paper: Warrendale, PA, USA, 2019.

50. Karavalakis, G.; Durbin, T.D.; Yang, J.; Ventura, L.; Xu, K. Fuel Effects on PM Emissions from Different Vehicle/Engine Configurations: A Literature Review; SAE Technical Paper: Warrendale, PA, USA, 2018.

51. Chan, T.W.; Meloche, E.; Kubsh, J.; Rosenblatt, D.; Brezny, R.; Rideout, G. Evaluation of a gasoline particulate filter to reduce particle emissions from a gasoline direct injection vehicle. SAE Int. J. Fuels Lubr. 2012, 5, 1277-1290. [CrossRef]

52. Zhan, R.; Eakle, S.T.; Weber, P. Simultaneous Reduction of PM, HC, CO and NOx Emissions from a GDI Engine; SAE Technical Paper: Warrendale, PA, USA, 2010.

53. Craig, A.; Warkins, J.; Aravelli, K.; Moser, D.; Yang, L.; Ball, D.; Tao, T.; Ross, D. Low cost LEV-III, Tier-III emission solutions with particulate control using advanced catalysts and substrates. SAE Int. J. Engines 2016, 9, 1276-1288. [CrossRef]

54. Tang, W.; Siani, A.; Chen, F.; Chen, B. On Developing Advanced Catalysts Systems to Meet China New Regulations; SAE Technical Paper: Warrendale, PA, USA, 2019.

55. Saito, C.; Nakatani, T.; Miyairi, Y.; Yuuki, K.; Makino, M.; Kurachi, H.; Heuss, W.; Kuki, T.; Furuta, Y.; Kattouah, P.; et al. New Particulate Filter Concept to Reduce Particle Number Emissions; SAE Technical Paper: Warrendale, PA, USA, 2011.

56. Jang, J.; Lee, J.; Choi, Y.; Park, S. Reduction of particle emissions from gasoline vehicles with direct fuel injection systems using a gasoline particulate filter. Sci. Total Environ. 2018, 644, 1418-1428. [CrossRef] [PubMed]

57. Spiess, S.; Wong, K.-F.; Richter, J.-M.; Klingmann, R. Investigations of emission control systems for gasoline direct injection engines with a focus on removal of particulate emissions. Top. Catal. 2013, 56, 434-439. [CrossRef]

58. Richter, J.M.; Klingmann, R.; Spiess, S.; Wong, K.-F. Application of catalyzed gasoline particulate filters to GDI vehicles. SAE Int. J. Engines 2012, 5, 1361-1370. [CrossRef]

59. Morgan, C. Platinum group metal and washcoat chemistry effects on coated gasoline particulate filter design. Johnson Matthey Technol. Rev. 2015, 59, 188-192. [CrossRef]

60. Ito, Y.; Shimoda, T.; Aoki, T.; Yuuki, K.; Sakamoto, H.; Kato, K.; Thier, D.; Kattouah, P.; Ohara, E.; Vogt, C. Next Generation of Ceramic Wall Flow Gasoline Particulate Filter with Integrated Three Way Catalyst; SAE Technical Paper: Warrendale, PA, USA, 2015.

61. Xia, W.; Zheng, Y.; He, X.; Yang, D.; Shao, H.; Remias, J.; Roos, J.; Wang, Y. Catalyzed Gasoline Particulate Filter (GPF) Performance: Effect of Driving Cycle, Fuel, Catalyst Coating; SAE Technical Paper: Warrendale, PA, USA, 2017.

62. Shao, H.; Carpentier, G.; Yin, D.; Wang, Y.; Remias, J.; Roos, J.; Xia, W.; Zheng, Y.; Yuan, X.; Yang, D.; et al. Engine Accelerated Aging Method Developed to Study the Effect of Lubricant Formulations on Catalyzed Gasoline Particulate Filter Durability; SAE Technical Paper: Warrendale, PA, USA, 2018.

63. Kern, B.; Spiess, S.; Richter, J.M. Comprehensive Gasoline Exhaust Gas Aftertreatment, an Effective Measure to Minimize the Contribution of Modern Direct Injection Engines to Fine Dust and Soot Emisions? SAE Technical Paper: Warrendale, PA, USA, 2014.

64. Maricq, M.M.; Szente, J.J.; Adams, J.; Tennison, P.; Rumpsa, T. Influence of mileage accumulation on the particle mass and number emissions of two gasoline direct injection vehicles. Environ. Sci. Technol. 2013, 47, 11890-11896. [CrossRef]

65. Lambert, C.K.; Bumbaroska, M.; Dobson, D.; Hangas, J.; Pakko, J.; Tennison, P. Analysis of high mileage gasoline exhaust particle filters. SAE Int. J. Engines 2016, 9, 1296-1304. [CrossRef]

66. Chijiiwa, R.; Rose, D.; Nicolin, P.; Coulet, B.; Jung, F.; Glasson, T.; Lv, Z.; Bachurina, A.; Shimizu, M.; Boger, T. Ash Accumulation in Advanced Gasoline Particulate Filter Technologies; JSAE: Yokohama, Japan, 2018; p. 20185404.

67. Liu, X.; Chanko, T.; Lambert, C.; Maricq, M. Gasoline Particulate Filter Efficiency and Backpressure at Very Low Mileage; SAE Technical Paper: Warrendale, PA, USA, 2018.

68. Zhang, R.; Howard, K.; Kirkman, P.; Browne, D.; Lu, Z.; He, S.; Boger, T. A Study into the Impact of Engine Oil on Gasoline Particulate Filter Performance through a Real-World Fleet Test; SAE Technical Paper: Warrendale, PA, USA, 2019.

69. Liu, X.; Szente, J.; Pakko, J.; Lambert, C.; Maricq, M. Using Artificial Ash to Improve GPF Performance at Zero Mileage; SAE Technical Paper: Warrendale, PA, USA, 2019. 
70. Nicolin, P.; Rose, D.; Kunath, F.; Boger, T. Modeling of the soot oxidation in gasoline particulate filters. SAE Int. J. Engines 2015, 8, 1253-1260. [CrossRef]

71. Easter, J.E.; Fiano, A.; Bohac, S.; Premchand, K.; Hoard, J. Evaluation of Low Mileage GPF Filtration and Regeneration as Influenced by Soot Morphology, Reactivity, and GPF Loading; SAE Technical Paper: Warrendale, PA, USA, 2019.

72. Van Nieuwstadt, M.; Shah, A.; Serban, E.; Martin, D. Regeneration Strategies for Gasoline Particulate Filters; SAE Technical Paper: Warrendale, PA, USA, 2019.

73. Boger, T.; Rose, D.; Nicolin, P.; Coulet, B.; Bachurina, A. Severe Soot Oxidations in Gasoline Particulate Filter Applications; SAE Technical Paper: Warrendale, PA, USA, 2018.

74. Chan, T.W.; Saffaripour, M.; Liu, F.; Hendren, J.; Thomson, K.A.; Kubsh, J.; Brezny, R.; Rideout, G. Characterization of real-time particle emissions from a gasoline direct injection vehicle equipped with a catalyzed gasoline particulate filter during filter regeneration. Emiss. Control. Sci. Technol. 2016, 2, 75-88. [CrossRef]

75. Giechaskiel, B.; Lähde, T.; Suarez-Bertoa, R.; Clairotte, M.; Grigoratos, T.; Zardini, A.; Perujo, A.; Martini, G. Particle number measurements in the European legislation and future JRC activities. Combust. Engines 2018, 174, 3-16.

76. Giechaskiel, B. Differences between tailpipe and dilution tunnel sub-23 nm non-volatile (solid) particle number measurements. Aerosol Sci. Technol. 2019, 1-13, in press. [CrossRef]

77. Berg, W. Legislation for the reduction of exhaust gas emissions. In Traffic and Environment; Gruden, D., Ed.; Springer: Berlin/Heidelberg, Germany, 2003; Volume 3, pp. 175-253. ISBN 978-3-540-00050-1.

78. Truex, T.J. Interaction of Sulfur with Automotive Catalysts and the Impact on Vehicle Emissions-A Review; SAE Technical Paper: Warrendale, PA, USA, 1999.

79. Giechaskiel, B.; Maricq, M.; Ntziachristos, L.; Dardiotis, C.; Wang, X.; Axmann, H.; Bergmann, A.; Schindler, W. Review of motor vehicle particulate emissions sampling and measurement: From smoke and filter mass to particle number. J. Aerosol Sci. 2014, 67, 48-86. [CrossRef]

80. Giechaskiel, B.; Mamakos, A.; Andersson, J.; Dilara, P.; Martini, G.; Schindler, W.; Bergmann, A. Measurement of automotive nonvolatile particle number emissions within the European legislative framework: A review. Aerosol Sci. Technol. 2012, 46, 719-749. [CrossRef]

81. Giechaskiel, B.; Dilara, P.; Sandbach, E.; Andersson, J. Particle measurement programme (PMP) light-duty inter-laboratory exercise: Comparison of different particle number measurement systems. Meas. Sci. Technol. 2008, 19, 095401. [CrossRef]

82. Pavlovic, J.; Ciuffo, B.; Fontaras, G.; Valverde, V.; Marotta, A. How much difference in type-approval $\mathrm{CO}_{2}$ emissions from passenger cars in Europe can be expected from changing to the new test procedure (NEDC vs. WLTP)? Transp. Res. Part A Policy Pract. 2018, 111, 136-147. [CrossRef]

83. Weiss, M.; Bonnel, P.; Hummel, R.; Provenza, A.; Manfredi, U. On-road emissions of light-duty vehicles in europe. Environ. Sci. Technol. 2011, 45, 8575-8581. [CrossRef]

84. Carslaw, D.C.; Rhys-Tyler, G. New insights from comprehensive on-road measurements of NOx, NO2 and NH3 from vehicle emission remote sensing in London, UK. Atmos. Environ. 2013, 81, 339-347. [CrossRef]

85. Giechaskiel, B.; Clairotte, M.; Valverde-Morales, V.; Bonnel, P.; Kregar, Z.; Franco, V.; Dilara, P. Framework for the assessment of PEMS (Portable Emissions Measurement Systems) uncertainty. Environ. Res. 2018, 166, 251-260. [CrossRef]

86. Merkisz, J.; Fuc, P.; Lijewski, P.; Bielaczyc, P. The Comparison of the Emissions from Light Duty Vehicle in On-Road and NEDC Tests; SAE Technical Paper: Warrendale, PA, USA, 2010.

87. Yang, L. Real-World Emissions in China: A Meta-Study of PEMS Emissions Data from China 0 to China5/V lightand Heavy-Duty Vehicles; International Council on Clean Transportation: Washington, DC, USA, 2018.

88. Giechaskiel, B.; Riccobono, F.; Bonnel, P. Feasibility Study on the Extension of the Real Driving Emissions (RDE) Procedure to Particle Number (PN): Experimental Evaluation of Portable Emission Measurement Systems (PEMS) with Diffusion Chargers (DCs) to Measure Particle Number (PN) Concentration; Publications Office: Luxembourg, 2014.

89. Giechaskiel, B.; Riccobono, F.; Bonnel, P. Feasibility Study on the Extension of the Real Driving Emissions (RDE) Procedure to Particle Number (PN): Chassis Dynamometer Evaluation of Portable Emission Measurement Systems (PEMS) to Measure Particle Number (PN) Concentration: Phase II; Publications Office: Luxembourg, 2015; ISBN 978-92-79-51003-8. 
90. Riccobono, F.; Giechaskiel, B.; Mendoza Villafuerte, P. Particle Number PEMS Inter-Laboratory Comparison Exercise; Publications Office: Luxembourg, 2016.

91. Sonntag, D.B.; Baldauf, R.W.; Yanca, C.A.; Fulper, C.R. Particulate matter speciation profiles for light-duty gasoline vehicles in the United States. J. Air Waste Manag. Assoc. 2014, 64, 529-545. [CrossRef]

92. Nam, E.; Kishan, S.; Baldauf, R.W.; Fulper, C.R.; Sabisch, M.; Warila, J. Temperature effects on particulate matter emissions from light-duty, gasoline-powered motor vehicles. Environ. Sci. Technol. 2010, 44, 4672-4677. [CrossRef]

93. Mohr, M.; Lehmann, U.; Margaria, G. ACEA Programme on the Emissions of Fine Particulates from Passenger Cars(2) Part1: Particle Characterisation of a Wide Range of Engine Technologies; SAE Technical Paper: Warrendale, PA, USA, 2003.

94. Fushimi, A.; Kondo, Y.; Kobayashi, S.; Fujitani, Y.; Saitoh, K.; Takami, A.; Tanabe, K. Chemical composition and source of fine and nanoparticles from recent direct injection gasoline passenger cars: Effects of fuel and ambient temperature. Atmos. Environ. 2016, 124, 77-84. [CrossRef]

95. Andersson, J.D.; Wedekind, B.G.A.; Hall, D.; Stradling, R.; Wilson, G. DETR/SMMT/CONCAWE Particulate Research Programme: Light Duty Results; SAE Technical Paper: Warrendale, PA, USA, 2001.

96. Bosteels, D.; May, J.; Karlsson, H.; de Serves, C. 'Regulated' and 'Non-Regulated' Emissions from Modern European Passenger Cars; SAE Technical Paper: Warrendale, PA, USA, 2006.

97. Xing, J.; Shao, L.; Zheng, R.; Peng, J.; Wang, W.; Guo, Q.; Wang, Y.; Qin, Y.; Shuai, S.; Hu, M. Individual particles emitted from gasoline engines: Impact of engine types, engine loads and fuel components. J. Clean. Prod. 2017, 149, 461-471. [CrossRef]

98. Wang, Y.; Zheng, R.; Shuai, S.-J.; Qin, Y.; Peng, J.; Niu, H.; Li, M.; Wu, Y.; Lu, S.; Hu, M. The Impact of Fuel Properties from Chinese Market on the Particulate and VOCs Emissions of a PFI and a DIG Engine; SAE Technical Paper: Warrendale, PA, USA, 2016.

99. Schauer, J.J.; Christensen, C.G.; Kittelson, D.B.; Johnson, J.P.; Watts, W.F. Impact of ambient temperatures and driving conditions on the chemical composition of particulate matter emissions from non-smoking gasoline-powered motor vehicles. Aerosol Sci. Technol. 2008, 42, 210-223. [CrossRef]

100. Karavalakis, G.; Short, D.; Vu, D.; Russell, R.; Hajbabaei, M.; Asa-Awuku, A.; Durbin, T.D. Evaluating the effects of aromatics content in gasoline on gaseous and particulate matter emissions from SI-PFI and SIDI vehicles. Environ. Sci. Technol. 2015, 49, 7021-7031. [CrossRef]

101. Zielinska, B.; Sagebiel, J.; McDonald, J.D.; Whitney, K.; Lawson, D.R. Emissions rates and comparative chemical composition from selected in-use diesel and gasoline-fueled vehicles. J. Air Waste Manag. Assoc. 2004, 54, 1138-1150. [CrossRef]

102. Timonen, H.; Karjalainen, P.; Saukko, E.; Saarikoski, S.; Aakko-Saksa, P.; Simonen, P.; Murtonen, T.; Dal Maso, M.; Kuuluvainen, H.; Bloss, M.; et al. Influence of fuel ethanol content on primary emissions and secondary aerosol formation potential for a modern flex-fuel gasoline vehicle. Atmos. Chem. Phys. 2017, 17, 5311-5329. [CrossRef]

103. Yang, J.; Roth, P.; Ruehl, C.R.; Shafer, M.M.; Antkiewicz, D.S.; Durbin, T.D.; Cocker, D.; Asa-Awuku, A.; Karavalakis, G. Physical, chemical, and toxicological characteristics of particulate emissions from current technology gasoline direct injection vehicles. Sci. Total Environ. 2019, 650, 1182-1194. [CrossRef]

104. Karavalakis, G.; Short, D.; Chen, V.; Espinoza, C.; Berte, T.; Durbin, T.; Asa-Awuku, A.; Jung, H.; Ntziachristos, L.; Amanatidis, S.; et al. Evaluating Particulate Emissions from a Flexible Fuel Vehicle with Direct Injection when Operated on Ethanol and Iso-Butanol Blends; SAE Technical Paper: Warrendale, PA, USA, 2014.

105. Khalek, I.A.; Bougher, T.; Jetter, J.J. Particle emissions from a 2009 gasoline direct injection engine using different commercially available fuels. SAE Int. J. Fuels Lubr. 2010, 3, 623-637. [CrossRef]

106. Maricq, M.M. Monitoring motor vehicle PM emissions: An evaluation of three portable low-cost aerosol instruments. Aerosol Sci. Technol. 2013, 47, 564-573. [CrossRef]

107. Maricq, M.M.; Szente, J.J.; Harwell, A.L.; Loos, M.J. Impact of aggressive drive cycles on motor vehicle exhaust PM emissions. J. Aerosol Sci. 2017, 113, 1-11. [CrossRef]

108. Maricq, M.M.; Szente, J.J.; Jahr, K. The impact of ethanol fuel blends on PM emissions from a light-duty GDI vehicle. Aerosol Sci. Technol. 2012, 46, 576-583. [CrossRef] 
109. Yang, J.; Roth, P.; Zhu, H.; Durbin, T.D.; Karavalakis, G. Impacts of gasoline aromatic and ethanol levels on the emissions from GDI vehicles: Part 2. Influence on particulate matter, black carbon, and nanoparticle emissions. Fuel 2019, 252, 212-820. [CrossRef]

110. Choi, S.; Seong, H. Oxidation characteristics of gasoline direct-injection (GDI) engine soot: Catalytic effects of ash and modified kinetic correlation. Combust. Flame 2015, 162, 2371-2389. [CrossRef]

111. Price, P.; Stone, R.; OudeNijeweme, D.; Chen, X. Cold Start Particulate Emissions from a Second Generation DI Gasoline Engine; SAE Technical Paper: Warrendale, PA, USA, 2007.

112. Wang, C.; Xu, H.; Herreros, J.M.; Lattimore, T.; Shuai, S. Fuel effect on particulate matter composition and soot oxidation in a direct-injection spark ignition (DISI) engine. Energy Fuels 2014, 28, 2003-2012. [CrossRef]

113. Zelenyuk, A.; Wilson, J.; Imre, D.; Stewart, M.; Muntean, G.; Storey, J.; Prikhodko, V.; Lewis, S.; Eibl, M.; Parks, J. Detailed characterization of particulate matter emitted by lean-burn gasoline direct injection engine. Int. J. Engine Res. 2017, 18, 560-572. [CrossRef]

114. Rubino, L.; Thier, D.; Schumann, T.; Guettler, S.; Russ, G. Fundamental Study of GPF Performance on Soot and ash Accumulation Over Artemis Urban and Motorway Cycles-Comparison of Engine Bench Results with GPF Durability Study on Road; SAE Technical Paper: Warrendale, PA, USA, 2017.

115. Muñoz, M.; Haag, R.; Zeyer, K.; Mohn, J.; Comte, P.; Czerwinski, J.; Heeb, N.V. Effects of four prototype gasoline particle filters (GPFs) on nanoparticle and genotoxic PAH emissions of a gasoline direct injection (GDI) vehicle. Environ. Sci. Technol. 2018, 52, 10709-10718. [CrossRef]

116. Luo, Y.; Zhu, L.; Fang, J.; Zhuang, Z.; Guan, C.; Xia, C.; Xie, X.; Huang, Z. Size distribution, chemical composition and oxidation reactivity of particulate matter from gasoline direct injection (GDI) engine fueled with ethanol-gasoline fuel. Appl. Therm. Eng. 2015, 89, 647-655. [CrossRef]

117. Su, Y.; Xie, F.; Hong, W.; Li, X.; Hu, T. Experimental study of particulate emission characteristics from a gasoline direct injection engine during starting process. Int. J. Automot. Technol. 2019, 20, 411-421. [CrossRef]

118. Hong, W.; Yuan, C.; Xie, F.; Su, Y.; Chen, J. Particulate matter and particle-bound PAHs emissions from gasoline direct injection (GDI) engine with methanol-gasoline blended fuel during start. Int. J. Automot. Technol. 2018, 19, 717-726. [CrossRef]

119. Kim, K.-H.; Jahan, S.A.; Kabir, E.; Brown, R.J.C. A review of airborne polycyclic aromatic hydrocarbons (PAHs) and their human health effects. Environ. Int. 2013, 60, 71-80. [CrossRef]

120. Yang, J.; Roth, P.; Durbin, T.D.; Johnson, K.C.; Cocker, D.R.; Asa-Awuku, A.; Brezny, R.; Geller, M.; Karavalakis, G. Gasoline particulate filters as an effective tool to reduce particulate and polycyclic aromatic hydrocarbon emissions from gasoline direct injection (GDI) vehicles: A case study with two GDI vehicles. Environ. Sci. Technol. 2018, 52, 3275-3284. [CrossRef]

121. Braisher, M.; Stone, R.; Price, P. Particle Number Emissions from a Range of European Vehicles; SAE Technical Paper: Warrendale, PA, USA, 2010.

122. Whitaker, P.; Kapus, P.; Ogris, M.; Hollerer, P. Measures to reduce particulate emissions from gasoline DI engines. SAE Int. J. Engines 2011, 4, 1498-1512. [CrossRef]

123. McAllister, M.; Smith, S.; Kapus, P.; Vidmar, K.; Hochnetz, A. EU6c particle number on a full Size SUV-Engine out or GPF? SAE Int. J. Fuels Lubr. 2014, 7, 995-1003. [CrossRef]

124. Merkisz, J.; Pielecha, J.; Bielaczyc, P.; Woodburn, J. Analysis of Emission Factors in RDE Tests as Well as in NEDC and WLTC Chassis Dynamometer Tests; SAE Technical Paper: Warrendale, PA, USA, 2016.

125. Pielecha, J.; Merkisz, J.; Markowski, J.; Jasiński, R. Analysis of passenger car emission factors in RDE tests. E3S Web Conf. 2016, 10, 00073. [CrossRef]

126. Giechaskiel, B.; Riccobono, F.; Vlachos, T.; Mendoza-Villafuerte, P.; Suarez-Bertoa, R.; Fontaras, G.; Bonnel, P.; Weiss, M. Vehicle emission factors of solid nanoparticles in the laboratory and on the road using portable emission measurement systems (PEMS). Front. Environ. Sci. 2015, 3, 82. [CrossRef]

127. Giechaskiel, B.; Lähde, T.; Drossinos, Y. Regulating particle number measurements from the tailpipe of light-duty vehicles: The next step? Environ. Res. 2019, 172, 1-9. [CrossRef]

128. Merkisz, J.; Bielaczyc, P.; Pielecha, J.; Woodburn, J. RDE Testing of Passenger Cars: The Effect of the Cold Start on the Emissions Results; SAE Technical Paper: Warrendale, PA, USA, 2019.

129. Rodriguez, F.; Dornoff, J. Beyond NOx: Emissions of Unregulated Pollutants from a Modern Gasoline Car; ICCT: Washington, DC, USA, 2019. 
130. Wen, Y.; Wang, Y.; Fu, C.; Deng, W.; Zhan, Z.; Tang, Y.; Li, X.; Ding, H.; Shuai, S. The Impact of Injector Deposits on Spray and Particulate Emission of Advanced Gasoline Direct Injection Vehicle; SAE Technical Paper: Warrendale, PA, USA, 2016.

131. Lambert, C.K.; Chanko, T.; Jagner, M.; Hangas, J.; Liu, X.; Pakko, J.; Kamp, C.J. Analysis of ash in low mileage, rapid aged, and high mileage gasoline exhaust particle filters. SAE Int. J. Engines 2017, 10, 1595-1603. [CrossRef]

132. Bosteels, D. Real driving emissions of a GPF-equipped production car 2015. In Proceedings of the 3rd International Conference on Real Driving Emissions, Berlin, Germany, 27-29 October 2015.

133. ACEA. RDE 3 Data from European Automobile Manufacturers Association (ACEA). Available online: https://www.acea.be/publications/article/access-to-euro-6-rde-monitoring-data (accessed on 3 July 2019).

134. JAMA. RDE 3 Data from Japan Automobile Manufacturers Association (JAMA). Available online: http: //www.jama-english.jp/europe/publications/rde.html (accessed on 3 July 2019).

135. Merkisz, J.; Pielecha, J. Observations from PEMS testing of combustion engines of different applications. Combust. Engines 2018, 174, 40-55.

136. Merkisz, J.; Brzezinski, L.; Magdziak, A.; Skobiej, K. Analysis of particle emissions of passenger cars in RDE tests. E3S Web Conf. 2018, 44, 00108. [CrossRef]

137. Valverde, V.; Mora, B.A.; Clairotte, M.; Pavlovic, J.; Suarez-Bertoa, R.; Giechaskiel, B.; Astorga-LLorens, C.; Fontaras, G. Emissions factors derived from 13 Euro $6 \mathrm{~b}$ light-duty vehicles based on laboratory and on-road measurements. Atmosphere 2019, 10, 243. [CrossRef]

138. Alföldy, B.; Giechaskiel, B.; Hofmann, W.; Drossinos, Y. Size-distribution dependent lung deposition of diesel exhaust particles. J. Aerosol Sci. 2009, 40, 652-663. [CrossRef]

139. Harris, S.J.; Maricq, M.M. Signature size distributions for diesel and gasoline engine exhaust particulate matter. J. Aerosol Sci. 2001, 32, 749-764. [CrossRef]

140. Mathis, U.; Kaegi, R.; Mohr, M.; Zenobi, R. TEM analysis of volatile nanoparticles from particle trap equipped diesel and direct-injection spark-ignition vehicles. Atmos. Environ. 2004, 38, 4347-4355. [CrossRef]

141. Barone, T.L.; Storey, J.M.E.; Youngquist, A.D.; Szybist, J.P. An analysis of direct-injection spark-ignition (DISI) soot morphology. Atmos. Environ. 2012, 49, 268-274. [CrossRef]

142. Fujitani, Y.; Saitoh, K.; Kondo, Y.; Fushimi, A.; Takami, A.; Tanabe, K.; Kobayashi, S. Characterization of structure of single particles from various automobile engines under steady-state conditions. Aerosol Sci. Technol. 2016, 50, 1055-1067. [CrossRef]

143. Lee, K.O.; Seong, H.; Sakai, S.; Hageman, M.; Rothamer, D. Detailed Morphological Properties of Nanoparticles from Gasoline Direct Injection Engine Combustion of Ethanol Blends; SAE Technical Paper: Warrendale, PA, USA, 2013.

144. Gaddam, C.K.; Vander Wal, R.L. Physical and chemical characterization of SIDI engine particulates. Combust. Flame 2013, 160, 2517-2528. [CrossRef]

145. Seong, H.; Choi, S.; Lee, K. Examination of nanoparticles from gasoline direct-injection (GDI) engines using transmission electron microscopy (TEM). Int. J. Automot. Technol. 2014, 15, 175-181. [CrossRef]

146. Uy, D.; Ford, M.A.; Jayne, D.T.; O’Neill, A.E.; Haack, L.P.; Hangas, J.; Jagner, M.J.; Sammut, A.; Gangopadhyay, A.K. Characterization of gasoline soot and comparison to diesel soot: Morphology, chemistry, and wear. Tribol. Int. 2014, 80, 198-209. [CrossRef]

147. Saffaripour, M.; Chan, T.W.; Liu, F.; Thomson, K.A.; Smallwood, G.J.; Kubsh, J.; Brezny, R. Effect of drive cycle and gasoline particulate filter on the size and morphology of soot particles emitted from a gasoline-direct-injection vehicle. Environ. Sci. Technol. 2015, 49, 11950-11958. [CrossRef]

148. Liati, A.; Schreiber, D.; Dimopoulos Eggenschwiler, P.; Arroyo Rojas Dasilva, Y.; Spiteri, A.C. Electron microscopic characterization of soot particulate matter emitted by modern direct injection gasoline engines. Combust. Flame 2016, 166, 307-315. [CrossRef]

149. Liati, A.; Schreiber, D.; Arroyo Rojas Dasilva, Y.; Dimopoulos Eggenschwiler, P. Ultrafine particle emissions from modern gasoline and diesel vehicles: An electron microscopic perspective. Environ. Pollut. 2018, 239, 661-669. [CrossRef]

150. Karjalainen, P.; Pirjola, L.; Heikkilä, J.; Lähde, T.; Tzamkiozis, T.; Ntziachristos, L.; Keskinen, J.; Rönkkö, T. Exhaust particles of modern gasoline vehicles: A laboratory and an on-road study. Atmos. Environ. 2014, 97, 262-270. [CrossRef] 
151. Rönkkö, T.; Pirjola, L.; Ntziachristos, L.; Heikkilä, J.; Karjalainen, P.; Hillamo, R.; Keskinen, J. Vehicle engines produce exhaust nanoparticles even when not fueled. Environ. Sci. Technol. 2014, 48, 2043-2050. [CrossRef]

152. Bielaczyc, P.; Woodburn, J.; Szczotka, A. Low ambient temperature cold start emissions of gaseous and solid pollutants from Euro 5 vehicles featuring direct and indirect injection spark-ignition engines. SAE Int. J. Fuels Lubr. 2013, 6, 968-976. [CrossRef]

153. Giechaskiel, B.; Arndt, M.; Schindler, W.; Bergmann, A.; Silvis, W.; Drossinos, Y. Sampling of non-volatile vehicle exhaust particles: A simplified guide. SAE Int. J. Engines 2012, 5, 379-399. [CrossRef]

154. Ntziachristos, L.; Giechaskiel, B.; Pistikopoulos, P.; Samaras, Z.; Mathis, U.; Mohr, M.; Ristimäki, J.; Keskinen, J.; Mikkanen, P.; Casati, R.; et al. Performance Evaluation of a Novel Sampling and Measurement System for Exhaust Particle Characterization; SAE Technical Paper: Warrendale, PA, USA, 2004.

155. Mamakos, A.; Ntziachristos, L.; Samaras, Z. Comparability of particle emission measurements between vehicle testing laboratories: A long way to go. Meas. Sci. Technol. 2004, 15, 1855-1866. [CrossRef]

156. Keskinen, J.; Rönkkö, T. Can real-world diesel exhaust particle size distribution be reproduced in the laboratory? A critical review. J. Air Waste Manag. Assoc. 2010, 60, 1245-1255. [CrossRef] [PubMed]

157. Mohr, M.; Forss, A.-M.; Steffen, D. Particulate Emissions of Gasoline Vehicles and Influence of the Sampling Procedure; SAE Technical Paper: Warrendale, PA, USA, 2000.

158. Ntziachristos, L.; Mamakos, A.; Samaras, Z.; Mathis, U.; Mohr, M.; Thompson, N.; Stradling, R.; Forti, L.; De Serves, C. Overview of the European "Particulates" Project on the Characterization of Exhaust Particulate Emissions from Road Vehicles: Results for Light-Duty Vehicles; SAE Technical Paper: Warrendale, PA, USA, 2004.

159. Mohr, M.; Forss, A.-M.; Lehmann, U. Particle emissions from diesel passenger cars equipped with a particle trap in comparison to other technologies. Environ. Sci. Technol. 2006, 40, 2375-2383. [CrossRef] [PubMed]

160. Andersson, J.; Giechaskiel, B.; Munoz-Bueno, R.; Sandbach, E.; Dilara, P. Particle Measurement Programme $(P M P)$ Light-Duty Inter-Laboratory Correlation Exercise (ILCE_LD) Final Report; European Communities: Luxembourg, 2007.

161. Schreiber, D.; Forss, A.-M.; Mohr, M.; Dimopoulos, P. Particle Characterisation of Modern CNG, Gasoline and Diesel Passenger Cars; SAE Technical Paper: Warrendale, PA, USA, 2007.

162. Ericsson, P.; Holmström, M.; Amberntsson-Carlsson, A.; Ohlson, C.; Skoglundh, M.; Andersson, B.; Carlsson, P.-A. Characterization of Particulate Emissions and Methodology for Oxidation of Particulates from Non-Diesel Combustion Systems; SAE Technical Paper: Warrendale, PA, USA, 2008.

163. Mamakos, A.; Martini, G.; Marotta, A.; Manfredi, U. Assessment of different technical options in reducing particle emissions from gasoline direct injection vehicles. J. Aerosol Sci. 2013, 63, 115-125. [CrossRef]

164. Liang, B.; Ge, Y.; Tan, J.; Han, X.; Gao, L.; Hao, L.; Ye, W.; Dai, P. Comparison of PM emissions from a gasoline direct injected (GDI) vehicle and a port fuel injected (PFI) vehicle measured by electrical low pressure impactor (ELPI) with two fuels: Gasoline and M15 methanol gasoline. J. Aerosol Sci. 2013, 57, $22-31$. [CrossRef]

165. Bielaczyc, P.; Woodburn, J.; Szczotka, A. Particulate emissions from European vehicles featuring direct injection spark ignition engines tested under laboratory conditions. SAE Int. J. Fuels Lubr. 2014, 7, 580-590. [CrossRef]

166. Maricq, M.M.; Podsiadlik, D.H.; Chase, R.E. Examination of the size-resolved and transient nature of motor vehicle particle emissions. Environ. Sci. Technol. 1999, 33, 1618-1626. [CrossRef]

167. Maricq, M.M.; Podsiadlik, D.H.; Chase, R.E. Gasoline vehicle particle size distributions: Comparison of steady state, FTP, and US06 measurements. Environ. Sci. Technol. 1999, 33, 2007-2015. [CrossRef]

168. Ntziachristos, L.; Giechaskiel, B.; Pistikopoulos, P.; Fysikas, E.; Samaras, Z. Particle Emissions Characteristics of Different On-Road Vehicles; SAE Technical Paper: Warrendale, PA, USA, 2003.

169. Chan, T.W.; Meloche, E.; Kubsh, J.; Brezny, R.; Rosenblatt, D.; Rideout, G. Impact of ambient temperature on gaseous and particle emissions from a direct injection gasoline vehicle and its implications on particle filtration. SAE Int. J. Fuels Lubr. 2013, 6, 350-371. [CrossRef]

170. Zhang, S.; McMahon, W. Particulate emissions for LEV II light-duty gasoline direct injection vehicles. SAE Int. J. Fuels Lubr. 2012, 5, 637-646. [CrossRef]

171. Kim, J.; Choi, K.; Myung, C.-L.; Lee, Y.; Park, S. Comparative investigation of regulated emissions and nano-particle characteristics of light duty vehicles using various fuels for the FTP-75 and the NEDC mode. Fuel 2013, 106, 335-343. [CrossRef] 
172. Maricq, M.M.; Chase, R.E.; Xu, N.; Podsiadlik, D.H. The effects of the catalytic converter and fuel sulfur level on motor vehicle particulate matter emissions: Gasoline vehicles. Environ. Sci. Technol. 2002, 36, 276-282. [CrossRef] [PubMed]

173. Chang, M.-C.O.; Shields, J.E. Evaluation of solid particle number and black carbon for very low particulate matter emissions standards in light-duty vehicles. J. Air Waste Manag. Assoc. 2017, 67, 677-693. [CrossRef] [PubMed]

174. Lee, J.W.; Jeong, Y.I.; Jung, M.W.; Cha, K.O.; Kwon, S.I.; Kim, J.C.; Park, S. Experimental investigation and comparison of nanoparticle emission characteristics in light-duty vehicles for two different fuels. Int. J. Automot. Technol. 2008, 9, 397-403. [CrossRef]

175. Fu, H.; Wang, Y.; Li, X.; Shuai, S.-J. Impacts of COLD-start and Gasoline RON on Particulate Emission from Vehicles Powered by GDI and PFI Engines; SAE Technical Paper: Warrendale, PA, USA, 2014.

176. Zhu, R.; Hu, J.; Bao, X.; He, L.; Lai, Y.; Zu, L.; Li, Y.; Su, S. Tailpipe emissions from gasoline direct injection (GDI) and port fuel injection (PFI) vehicles at both low and high ambient temperatures. Environ. Pollut. 2016, 216, 223-234. [CrossRef] [PubMed]

177. Yamada, H.; Inomata, S.; Tanimoto, H. Particle and VOC emissions from stoichiometric gasoline direct injection vehicles and correlation between particle number and mass emissions. Emiss. Control. Sci. Technol. 2017, 3, 135-141. [CrossRef]

178. Jang, J.; Lee, J.; Kim, J.; Park, S. Comparisons of the nanoparticle emission characteristics between GDI and PFI vehicles. J. Nanopart. Res. 2015, 17, 486. [CrossRef]

179. Bielaczyc, P.; Szczotka, A.; Woodburn, J. An overview of particulate matter emissions from modern light duty vehicles. Combust. Engines 2013, 2, 101-108.

180. Bielaczyc, P.; Szczotka, A.; Woodburn, J. The impact of fuel ethanol content on particulate emissions from light-duty vehicles featuring spark ignition engines. SAE Int. J. Fuels Lubr. 2014, 7, 224-235. [CrossRef]

181. Olczyk, M.; Hejny, B.; Bielaczyc, P. An overview of particle number emission from direct injection SI engine in scope of new legislation rules. Combust. Engines 2015, 163, 67-78.

182. Bielaczyc, P.; Szczotka, A.; Woodburn, J. Regulated and unregulated exhaust emissions from CNG fueled vehicles in light of Euro 6 regulations and the new WLTP/GTR 15 test procedure. SAE Int. J. Engines 2015, 8, 1300-1312. [CrossRef]

183. Bielaczyc, P.; Woodburn, J.; Szczotka, A. Exhaust Emissions of Gaseous and Solid Pollutants Measured Over the NEDC, FTP-75 and WLTC Chassis Dynamometer Driving Cycles; SAE Technical Paper: Warrendale, PA, USA, 2016.

184. Li, Y.; Xue, J.; Johnson, K.; Durbin, T.; Villela, M.; Pham, L.; Hosseini, S.; Zheng, Z.; Short, D.; Karavalakis, G.; et al. Determination of Suspended Exhaust PM Mass for Light-Duty Vehicles; SAE Technical Paper: Warrendale, PA, USA, 2014.

185. Fulper, C.R.; Kishan, S.; Baldauf, R.W.; Sabisch, M.; Warila, J.; Fujita, E.M.; Scarbro, C.; Crews, W.S.; Snow, R.; Gabele, P.; et al. Methods of characterizing the distribution of exhaust emissions from light-duty, gasoline-powered motor vehicles in the U.S. fleet. J. Air Waste Manag. Assoc. 2010, 60, 1376-1387. [CrossRef] [PubMed]

186. Quiros, D.C.; Zhang, S.; Sardar, S.; Kamboures, M.A.; Eiges, D.; Zhang, M.; Jung, H.S.; Mccarthy, M.J.; Chang, M.-C.O.; Ayala, A.; et al. Measuring particulate emissions of light duty passenger vehicles using integrated particle size distribution (IPSD). Environ. Sci. Technol. 2015, 49, 5618-5627. [CrossRef]

187. Robert, M.A.; VanBergen, S.; Kleeman, M.J.; Jakober, C.A. Size and composition distributions of particulate matter emissions: Part 1-light-duty gasoline vehicles. J. Air Waste Manag. Assoc. 2007, 57, 1414-1428. [CrossRef] [PubMed]

188. Short, D.; Vu, D.; Chen, V.; Espinoza, C.; Berte, T.; Karavalakis, G.; Durbin, T.D.; Asa-Awuku, A. Understanding particles emitted from spray and wall-guided gasoline direct injection and flex fuel vehicles operating on ethanol and iso-butanol gasoline blends. Aerosol Sci. Technol. 2017, 51, 330-341. [CrossRef]

189. Saliba, G.; Saleh, R.; Zhao, Y.; Presto, A.A.; Lambe, A.T.; Frodin, B.; Sardar, S.; Maldonado, H.; Maddox, C.; May, A.A.; et al. Comparison of gasoline direct-injection (GDI) and port fuel injection (PFI) vehicle emissions: Emission certification standards, cold-start, secondary organic aerosol formation potential, and potential climate impacts. Environ. Sci. Technol. 2017, 51, 6542-6552. [CrossRef] [PubMed] 
190. Stradling, R.; Bazzani, R.; Bjordal, S.; Martinez, P.; Rickeard, D.J.; Schmelzle, P.; Scorletti, P.; Wolff, G.; Zemroch, P.J.; Thompson, N. Fuel Effects on Emissions from Modern Gasoline Vehicles. Part. 2-Aromatics, Olefins and Volatility Effects; Report 2/04; Concawe: Brussels, Belgium, 2004.

191. EPA. The Effects of Ultra-Low Sulfur Gasoline on Emissions from Tier 2 Vehicles in the In-Use Fleet: Final Study Report. Available online: https://www.epa.gov/moves/ultra-low-sulfur-gasoline-emissions-study (accessed on 3 July 2019).

192. Ahlvik, P.; Erlandsson, L.; Laveskog, A. The Influence of Block Heaters on the Emissions from Gasoline Fueled Cars with Varying Emission Control Technology at Low Ambient Temperatures; SAE Technical Paper: Warrendale, PA, USA, 1997; p. 970747.

193. Ball, J.C. Emission Rates and Elemental Composition of Particles Collected from 1995 Ford Vehicles Using the Urban Dynamometer Driving Schedule, the Highway Fuel Economy Test, and the USO6 Driving Cycle; SAE Technical Paper: Warrendale, PA, USA, 1997; p. 972914.

194. Vuk, C.; Vander Griend, S.J. Fuel Property Effects on Particulates in Spark Ignition Engines; SAE Technical Paper: Warrendale, PA, USA, 2013.

195. Hall, D.E.; Dickens, C.J. Measurement of the Number and Size Distribution of Particles Emitted from a Gasoline Direct Injection Vehicle; SAE Technical Paper: Warrendale, PA, USA, 1999.

196. Aakko, P.; Nylund, N.-O. Particle Emissions at Moderate and Cold Temperatures Using Different Fuels; SAE Technical Paper: Warrendale, PA, USA, 2003.

197. Peckham, M.S.; Finch, A.; Campbell, B.; Price, P.; Davies, M.T. Study of Particle Number Emissions from a Turbocharged Gasoline Direct Injection (GDI) Engine Including Data from a Fast-Response Particle Size Spectrometer; SAE Technical Paper: Warrendale, PA, USA, 2011.

198. Choi, K.; Kim, J.; Myung, C.-L.; Lee, M.; Kwon, S.; Lee, Y.; Park, S. Effect of the mixture preparation on the nanoparticle characteristics of gasoline direct-injection vehicles. Proc. Inst. Mech. Eng. Part D J. Automob. Eng. 2012, 226, 1514-1524. [CrossRef]

199. Choi, K.; Kim, J.; Ko, A.; Myung, C.-L.; Park, S.; Lee, J. Size-resolved engine exhaust aerosol characteristics in a metal foam particulate filter for GDI light-duty vehicle. J. Aerosol Sci. 2013, 57, 1-13. [CrossRef]

200. Bielaczyc, P.; Szczotka, A.; Woodburn, J. Exhaust emissions of particulate matter from light-duty vehicles-An overview and the current situation. Combust. Engines 2017, 171, 227-238.

201. Demuynck, J.; Favre, C.; Bosteels, D.; Hamje, H.; Andersson, J. Real-World Emissions Measurements of a Gasoline Direct Injection Vehicle Without and with a Gasoline Particulate Filter; SAE Technical Paper: Warrendale, PA, USA, 2017.

202. Ogata, T.; Makino, M.; Aoki, T.; Shimoda, T.; Kato, K.; Nakatani, T.; Nagata, K.; Vogt, C.D.; Ito, Y.; Thier, D. Particle Number Emission Reduction for GDI Engines with gasoline Particulate Filters; SAE Technical Paper: Warrendale, PA, USA, 2017.

203. Wang, X.; Ge, Y.; Liu, L.; Peng, Z.; Hao, L.; Yin, H.; Ding, Y.; Wang, J. Evaluation on toxic reduction and fuel economy of a gasoline direct injection- (GDI-) powered passenger car fueled with methanol-gasoline blends with various substitution ratios. Appl. Energy 2015, 157, 134-143. [CrossRef]

204. Karavalakis, G.; Short, D.; Vu, D.; Villela, M.; Russell, R.; Jung, H.; Asa-Awuku, A.; Durbin, T. Regulated emissions, air toxics, and particle emissions from SI-DI light-duty vehicles operating on different iso-butanol and ethanol blends. SAE Int. J. Fuels Lubr. 2014, 7, 183-199. [CrossRef]

205. Premnath, V.; Khalek, I.; Morgan, P.; Michlberger, A.; Sutton, M.; Vincent, P. Effect of Lubricant Oil on Particle Emissions from a Gasoline Direct Injection Light-Duty Vehicle; SAE Technical Paper: Warrendale, PA, USA, 2018.

206. Myung, C.-L.; Kim, J.; Choi, K.; Hwang, I.G.; Park, S. Comparative study of engine control strategies for particulate emissions from direct injection light-duty vehicle fueled with gasoline and liquid phase liquefied petroleum gas (LPG). Fuel 2012, 94, 348-355. [CrossRef]

207. Jin, D.; Choi, K.; Myung, C.-L.; Lim, Y.; Lee, J.; Park, S. The impact of various ethanol-gasoline blends on particulates and unregulated gaseous emissions characteristics from a spark ignition direct injection (SIDI) passenger vehicle. Fuel 2017, 209, 702-712. [CrossRef]

208. Zhu, R.; Hu, J.; Bao, X.; He, L.; Zu, L. Effects of aromatics, olefins and distillation temperatures (T50 \& T90) on particle mass and number emissions from gasoline direct injection (GDI) vehicles. Energy Policy 2017, 101, 185-193.

209. Köhler, F. Testing of Particulate Emissions from Positive Ignition Vehicles with Direct Fuel Injection System; TUV Nord: Hanover, Germany, 2013. 
210. Karavalakis, G.; Short, D.; Vu, D.; Russell, R.L.; Asa-Awuku, A.; Jung, H.; Johnson, K.C.; Durbin, T.D. The impact of ethanol and iso-butanol blends on gaseous and particulate emissions from two passenger cars equipped with spray-guided and wall-guided direct injection SI (spark ignition) engines. Energy 2015, 82, 168-179. [CrossRef]

211. Bielaczyc, P.; Woodburn, J.; Szczotka, A. Particulate emissions from passenger cars with DISI engines tested at sub-zero temperatures 2014. In Proceedings of the 18th ETH Conference on Combustion Generated Nanoparticles, Zurich, Switzerland, 22-25 June 2014.

212. Storey, J.M.; Barone, T.; Norman, K.; Lewis, S. Ethanol blend effects on direct injection spark-ignition gasoline vehicle particulate matter emissions. SAE Int. J. Fuels Lubr. 2010, 3, 650-659. [CrossRef]

213. Storey, J.M.E.; Barone, T.L.; Thomas, J.F.; Huff, S.P. Exhaust Particle Characterization for Lean and Stoichiometric DI Vehicles Operating on Ethanol-Gasoline Blends; SAE Technical Paper: Warrendale, PA, USA, 2012; pp. 2012-010437.

214. Bielaczyc, P.; Szczotka, A.; Woodburn, J. Investigations into Exhaust Particulate Emissions from Multiple Vehicle Types Running on Two Chassis Dynamometer Driving Cycles; SAE Technical Paper: Warrendale, PA, USA, 2017.

215. Ou, Q.; Maricq, M.M.; Pakko, J.; Chanko, T.B.; Pui, D.Y.H. Design and evaluation of a sintered metal fiber filter for gasoline direct injection engine exhaust aftertreatment. J. Aerosol Sci. 2019, 133, 12-23. [CrossRef]

216. Vu, D.; Roth, P.; Berte, T.; Yang, J.; Cocker, D.; Durbin, T.D.; Karavalakis, G.; Asa-Awuku, A. Using a new mobile atmospheric chamber (MACh) to investigate the formation of secondary aerosols from mobile sources: The case of gasoline direct injection vehicles. J. Aerosol Sci. 2019, 133, 1-11. [CrossRef]

217. Shields, J.E. Particulate Matter (PM) Emissions from Low Greenhouse Gas Engine Technologies. Presentation at the Advanced Clean Cars Symposium. Available online: https://ww2.arb.ca.gov/advanced-clean-carssymposium-september-2016 (accessed on 3 July 2019).

218. Ligterink, N. Emissions of Three Common GDI Vehicles; TNO: Hague, The Netherlands, 2016.

219. Storey, J.M.; Moses-DeBusk, M.; Huff, S.; Thomas, J.; Eibl, M.; Li, F. Characterization of GDI PM During Vehicle Start-Stop Operation; SAE Technical Paper: Warrendale, PA, USA, 2019.

220. Chambon, P.; Huff, S.; Norman, K.; Edwards, K.D.; Thomas, J.; Prikhodko, V. European Lean Gasoline Direct Injection Vehicle Benchmark; SAE Technical Paper: Warrendale, PA, USA, 2011.

221. Koczak, J.; Boehman, A.; Brusstar, M. Particulate Emissions in GDI Vehicle Transients: An Examination of FTP, HWFET, and US06 Measurements; SAE Technical Paper: Warrendale, PA, USA, 2016.

222. Zhao, Y.; Li, X.; Hu, S.; Ma, C. Effects of the particulate matter index and particulate evaluation index of the primary reference fuel on particulate emissions from gasoline direct injection vehicles. Atmosphere 2019, 10, 111. [CrossRef]

223. Chan, T.W.; Lax, D.; Gunter, G.C.; Hendren, J.; Kubsh, J.; Brezny, R. Assessment of the fuel composition impact on black carbon mass, particle number size distributions, solid particle number, organic materials, and regulated gaseous emissions from a light-duty gasoline direct injection truck and passenger car. Energy Fuels 2017, 31, 10452-10466. [CrossRef]

224. Favre, C.; Bosteels, D.; May, J. Exhaust Emissions from European Market-Available Passenger Cars Evaluated on Various Drive Cycles; SAE Technical Paper: Warrendale, PA, USA, 2013.

225. Weber, C.; Sundvor, I.; Figenbaum, E. Comparison of regulated emission factors of Euro 6 LDV in Nordic temperatures and cold start conditions: Diesel- and gasoline direct-injection. Atmos. Environ. 2019, 206, 208-217. [CrossRef]

226. Ristimäki, J.; Keskinen, J.; Virtanen, A.; Maricq, M.; Aakko, P. Cold temperature PM emissions measurement: Method evaluation and application to light duty vehicles. Environ. Sci. Technol. 2005, 39, 9424-9430. [CrossRef] [PubMed]

227. Aikawa, K.; Sakurai, T.; Jetter, J.J. Development of a predictive model for gasoline vehicle particulate matter emissions. SAE Int. J. Fuels Lubr. 2010, 3, 610-622. [CrossRef]

228. Czerwinski, J.; Comte, P.; Wichser, A.; Mayer, A.; Lemaire, J. Experiences from Nanoparticle Research on Four Gasoline Cars; SAE Technical Paper: Warrendale, PA, USA, 2015.

229. Czerwinski, J.; Comte, P.; Engelmann, D.; Heeb, N.; Muñoz, M.; Bonsack, P.; Hensel, V.; Mayer, A. PN-Emissions of Gasoline Cars MPI and Potentials of GPF; SAE Technical Paper: Warrendale, PA, USA, 2018.

230. Hensel, V.; Mayer, A.; Czerwinski, J.; Comte, P.; Engelmann, D. Nanoparticle emissions and GPF for MPI gasoline cars. IOP Conf. Ser. Mater. Sci. Eng. 2018, 421, 042027. [CrossRef] 
231. Chen, L.; Liang, Z.; Zhang, X.; Shuai, S. Characterizing particulate matter emissions from GDI and PFI vehicles under transient and cold start conditions. Fuel 2017, 189, 131-140. [CrossRef]

232. Clairotte, M.; Valverde, V.; Bonnel, P.; Giechaskiel, P.; Carriero, M.; Otura, M.; Fontaras, G.; Pavlovic, J.; Martini, G.; Krasenbrink, A. Joint Res. Centre 2017 Light-Duty Vehicles Emissions Testing Contribution to the EU Market Surveillance: Testing Protocols and Vehicle Emissions Performance; Publications Office: Luxembourg, 2018; ISBN 978-92-79-90600-8.

233. Lv, G.; Song, C.; Pan, S.; Gao, J.; Cao, X. Comparison of number, surface area and volume distributions of particles emitted from a multipoint port fuel injection car and a gasoline direct injection car. Atmos. Pollut. Res. 2014, 5, 753-758. [CrossRef]

234. Chan, T.W.; Meloche, E.; Kubsh, J.; Brezny, R. Black carbon emissions in gasoline exhaust and a reduction alternative with a gasoline particulate filter. Environ. Sci. Technol. 2014, 48, 6027-6034. [CrossRef]

235. Xue, J.; Li, Y.; Quiros, D.; Hu, S.; Huai, T.; Ayala, A.; Jung, H.S. Investigation of alternative metrics to quantify PM mass emissions from light duty vehicles. J. Aerosol Sci. 2017, 113, 85-94. [CrossRef]

236. Sogawa, Y.; Hattori, H.; Yanagisawa, N.; Hosoya, M.; Shoji, T.; Iwakiri, Y.; Yamashita, T.; Ikeda, T.; Tanaka, S.; Takahashi, K.; et al. Nano Particle Emission Evaluation of State of the Art Diesel Aftertreatment Technologies (DPF, Urea-SCR and DOC), Gasoline Combustion Systems (Lean Burn/Stoichiometric DISI and MPI) and Fuel Qualities Effects (EtOH, ETBE, FAME, Aromatics and Distillation); SAE Technical Paper: Warrendale, PA, USA, 2007.

237. Oh, C.; Cha, G. Impact of fuel, injection type and after-treatment system on particulate emissions of light-duty vehicles using different fuels on FTP-75 and HWFET test cycles. Int. J. Automot. Technol. 2015, 16, 895-901. [CrossRef]

238. He, L.; Hu, J.; Zhang, S.; Wu, Y.; Zhu, R.; Zu, L.; Bao, X.; Lai, Y.; Su, S. The impact from the direct injection and multi-port fuel injection technologies for gasoline vehicles on solid particle number and black carbon emissions. Appl. Energy 2018, 226, 819-826. [CrossRef]

239. Yang, L.; Bernard, Y.; Posada, F.; German, J. Laboratory and on-road testing of exhaust emissions of two modern China 5 light-duty gasoline vehicles; ICCT: Hamburg, Germany, 2018.

240. Suarez-Bertoa, R.; Astorga, C. Impact of cold temperature on Euro 6 passenger car emissions. Environ. Pollut. 2018, 234, 318-329. [CrossRef] [PubMed]

241. Yang, Z.; Ge, Y.; Thomas, D.; Wang, X.; Su, S.; Li, H.; He, H. Real driving particle number (PN) emissions from China-6 compliant PFI and GDI hybrid electrical vehicles. Atmos. Environ. 2019, 199, 70-79. [CrossRef]

242. Giechaskiel, B.; Casadei, S.; Mazzini, M.; Sammarco, M.; Montabone, G.; Tonelli, R.; Deana, M.; Costi, G.; Di Tanno, F.; Prati, M.; et al. Inter-laboratory correlation exercise with portable emissions measurement systems (PEMS) on chassis dynamometers. Appl. Sci. 2018, 8, 2275. [CrossRef]

243. Ito, Y.; Shimoda, T.; Aoki, T.; Shibagaki, Y.; Yuuki, K.; Sakamoto, H.; Vogt, C.; Matsumoto, T.; Heuss, W.; Kattouah, P.; et al. Advanced Ceramic Wall Flow Filter for Reduction of Particulate Number Emission of Direct Injection Gasoline Engines; SAE Technical Paper: Warrendale, PA, USA, 2013.

244. Gallus, J.; Kirchner, U.; Vogt, R.; Börensen, C.; Benter, T. On-road particle number measurements using a portable emission measurement system (PEMS). Atmos. Environ. 2016, 124, 37-45. [CrossRef]

245. Czerwinski, J.; Comte, P.; Heeb, N.; Mayer, A.; Hensel, V. Nanoparticle Emissions of DI Gasoline Cars with/without GPF; SAE Technical Paper: Warrendale, PA, USA, 2017.

246. Comte, P.; Czerwinski, J.; Keller, A.; Kumar, N.; Muñoz, M.; Pieber, S.; Prévôt, A.; Wichser, A.; Heeb, N. GASOMEP: Current Status and New Concepts of Gasoline Vehicle Emission Control for Organic, Metallic and Particulate Non-Legislative Pollutants; EMPA: Dübendorf, Switzerland, 2017.

247. Giechaskiel, B.; Vanhanen, J.; Väkevä, M.; Martini, G. Investigation of vehicle exhaust sub-23 nm particle emissions. Aerosol Sci. Technol. 2017, 51, 626-641. [CrossRef]

248. Ntziachristos, L.; Amanatidis, S.; Samaras, Z.; Giechaskiel, B.; Bergmann, A. Use of a catalytic stripper as an alternative to the original PMP measurement protocol. SAE Int. J. Fuels Lubr. 2013, 6, 532-541. [CrossRef]

249. Ko, J.; Kim, K.; Chung, W.; Myung, C.-L.; Park, S. Characteristics of on-road particle number (PN) emissions from a GDI vehicle depending on a catalytic stripper (CS) and a metal-foam gasoline particulate filter (GPF). Fuel 2019, 238, 363-374. [CrossRef]

250. Zhu, R.; Hu, J.; Bao, X.; He, L.; Lai, Y.; Zu, L.; Li, Y.; Su, S. Investigation of tailpipe and evaporative emissions from China IV and Tier 2 passenger vehicles with different gasolines. Transp. Res. Part D Transp. Environ. 2017, 50, 305-315. [CrossRef] 
251. Happonen, M.; Matilainen, P.; Kanniainen, K.; Kinnunen, T.; Karjalainen, P.; Heikkilä, J.; Ronkko, T.; Keskinen, J.; Lähde, T.; Malinen, A.; et al. The Effect of a Particle Oxidation Catalyst (POC®) on Particle Emissions of a GDI car During Transient Engine Operation; SAE Technical Paper: Warrendale, PA, USA, 2013.

252. OudeNijeweme, D.; Freeland, P.; Behringer, M.; Aleiferis, P. Developing Low Gasoline Particulate Emission Engines through Improved Fuel Delivery; SAE Technical Paper: Warrendale, PA, USA, 2014.

253. Zinola, S.; Raux, S.; Leblanc, M. Persistent Particle Number Emissions Sources at the Tailpipe of Combustion Engines; SAE Technical Paper: Warrendale, PA, USA, 2016.

254. Aikawa, K.; Jetter, J.J. Impact of gasoline composition on particulate matter emissions from a direct-injection gasoline engine: Applicability of the particulate matter index. Int. J. Engine Res. 2014, 15, 298-306. [CrossRef]

255. Stępień, Z.; Czerwinski, J.; Comte, P.; Oleksiak, S. Nanoparticle and non-legislated gaseous emissions from a gasoline direct-injection car with ethanol blend fuels and detergent additives. Energy Fuels 2016, 30, 7268-7276. [CrossRef]

256. Xia, W.; Yuan, X.; Yang, D.; Zheng, Y.; Zhao, D.; Wang, C.; He, X.; Shao, H.; Carpentier, G.; Remias, J.; et al. Design of Catalyzed Gasoline Particulate Filter (cGPF) and Investigation of Its Durability Performance Using Accelerated Engine Aging; SAE Technical Paper: Warrendale, PA, USA, 2019.

257. Suarez-Bertoa, R.; Pavlovic, J.; Trentadue, G.; Otura-Garcia, M.; Tansini, A.; Ciuffo, B.; Astorga, C. Effect of low ambient temperature on emissions and electric range of plug-in hybrid electric vehicles. ACS Omega 2019, 4, 3159-3168. [CrossRef]

258. Yang, J.; Roth, P.; Durbin, T.D.; Johnson, K.C.; Asa-Awuku, A.; Cocker, D.R.; Karavalakis, G. Investigation of the effect of mid- and high-level ethanol blends on the particulate and the mobile source air toxic emissions from a gasoline direct injection flex fuel vehicle. Energy Fuels 2019, 33, 429-440. [CrossRef]

259. Mathis, U.; Mohr, M.; Forss, A. Comprehensive particle characterization of modern gasoline and diesel passenger cars at low ambient temperatures. Atmos. Environ. 2005, 39, 107-117. [CrossRef]

260. Mayer, A.; Czerwinski, J.; Kasper, M.; Ulrich, A.; Mooney, J.J. Metal Oxide Particle Emissions from Diesel and Petrol Engines; SAE Technical Paper: Warrendale, PA, USA, 2012.

261. Guse, D.; Roehrich, H.; Lenz, M.; Pischinger, S. Influence of Vehicle Operators and Fuel Grades on Particulate Emissions of an SI Engine in Dynamic Cycles; SAE Technical Paper: Warrendale, PA, USA, 2018.

262. Robinson, M.K.; Holmén, B.A. Onboard, real-world second-by-second particle number emissions from 2010 hybrid and comparable conventional vehicles. Transp. Res. Rec. 2011, 2233, 63-71. [CrossRef]

263. Graskow, B.R.; Kittelson, D.B.; Ahmadi, M.R.; Morris, J.E. Exhaust Particulate Emissions from a Direct Injection Spark Ignition Engine; SAE Technical Paper: Warrendale, PA, USA, 1999.

264. Xue, J.; Li, Y.; Wang, X.; Durbin, T.D.; Johnson, K.C.; Karavalakis, G.; Asa-Awuku, A.; Villela, M.; Quiros, D.; $\mathrm{Hu}$, S.; et al. Comparison of vehicle exhaust particle size distributions measured by SMPS and EEPS during steady-state conditions. Aerosol Sci. Technol. 2015, 49, 984-996. [CrossRef]

265. Hall, D.E.; Goodfellow, C.L.; Heinze, P.; Rickeard, D.J.; Nancekievill, G.; Martini, G.; Hevesi, J.; Rantanen, L.; Merino, P.M.; Morgan, T.D.B.; et al. A Study of the Size, Number and Mass Distribution of the Automotive Particulate Emissions from European Light Duty Vehicles; SAE Technical Paper: Warrendale, PA, USA, 1998; p. 982600.

266. Costagliola, M.A.; Prati, M.V.; Mariani, A.; Unich, A.; Morrone, B. Gaseous and particulate exhaust emissions of hybrid and conventional cars over legislative and real driving cycles. Energy Power Eng. 2015, 7, 181-192. [CrossRef]

267. Du, Z.; Hu, M.; Peng, J.; Zhang, W.; Zheng, J.; Gu, F.; Qin, Y.; Yang, Y.; Li, M.; Wu, Y.; et al. Comparison of primary aerosol emission and secondary aerosol formation from gasoline direct injection and port fuel injection vehicles. Atmos. Chem. Phys. 2018, 18, 9011-9023. [CrossRef]

268. Huang, C.; Lou, D.; Hu, Z.; Feng, Q.; Chen, Y.; Chen, C.; Tan, P.; Yao, D. A PEMS study of the emissions of gaseous pollutants and ultrafine particles from gasoline- and diesel-fueled vehicles. Atmos. Environ. 2013, 77, 703-710. [CrossRef]

269. Myung, C.-L.; Kim, J.; Jang, W.; Jin, D.; Park, S.; Lee, J. Nanoparticle filtration characteristics of advanced metal foam media for a spark ignition direct injection engine in steady engine operating conditions and vehicle test modes. Energies 2015, 8, 1865-1881. [CrossRef]

270. Zimmerman, N.; Wang, J.M.; Jeong, C.-H.; Ramos, M.; Hilker, N.; Healy, R.M.; Sabaliauskas, K.; Wallace, J.S.; Evans, G.J. Field measurements of gasoline direct injection emission factors: Spatial and seasonal variability. Environ. Sci. Technol. 2016, 50, 2035-2043. [CrossRef] [PubMed] 
271. Louis, C.; Liu, Y.; Tassel, P.; Perret, P.; Chaumond, A.; André, M. PAH, BTEX, carbonyl compound, black-carbon, $\mathrm{NO}_{2}$ and ultrafine particle dynamometer bench emissions for Euro 4 and Euro 5 diesel and gasoline passenger cars. Atmos. Environ. 2016, 141, 80-95. [CrossRef]

272. Cédric, L.; Goriaux, M.; Tassel, P.; Perret, P.; André, M.; Liu, Y. Impact of aftertreatment device and driving conditions on black carbon, ultrafine particle and NOx emissions for Euro 5 diesel and gasoline vehicles. Transp. Res. Procedia 2016, 14, 3079-3088. [CrossRef]

273. Chirico, R.; Clairotte, M.; Adam, T.W.; Giechaskiel, B.; Heringa, M.F.; Elsasser, M.; Martini, G.; Manfredi, U.; Streibel, T.; Sklorz, M.; et al. Emissions of organic aerosol mass, black carbon, particle number, and regulated and unregulated gases from scooters and light and heavy duty vehicles with different fuels. Atmos. Chem. Phys. Discuss. 2014, 14, 16591-16639. [CrossRef]

274. Karavalakis, G.; Short, D.; Vu, D.; Villela, M.; Asa-Awuku, A.; Durbin, T.D. Evaluating the regulated emissions, air toxics, ultrafine particles, and black carbon from SI-PFI and SI-DI vehicles operating on different ethanol and iso-butanol blends. Fuel 2014, 128, 410-421. [CrossRef]

(C) 2019 by the authors. Licensee MDPI, Basel, Switzerland. This article is an open access article distributed under the terms and conditions of the Creative Commons Attribution (CC BY) license (http://creativecommons.org/licenses/by/4.0/). 